\title{
Güneydoğu Anadolu'da Neolitik Dönem Dikilitaş Geleneği: Bağlamsal Yaklaşımla Karşılaştırmalı Bir Değerlendirme
}

\section{Neolithic Stone Pillar Tradition in Southeast Anatolia: A Comparative Assessment Using a Contextual Approach}

\author{
Erhan Bingöl ${ }^{1}$
}

1Protohistorya ve Önasya Arkeolojisi, Adana, Türkiye

\section{ORCID ID: E.B. 0000-0002-1945-8586}

Sorumlu yazar/Corresponding author: Erhan Bingöl,

Protohistorya ve Önasya Arkeolojisi,

Adana, Türkiye

E-posta: erhanbingol12@gmail.com

Başvuru/Submitted: 03.09.2021

Revizyon Talebi/Revision Requested: 08.10.2021 Son Revizyon/Last Revision Received: 03.11.2021 Kabul/Accepted: 09.11.2021

Atıf/Citation: Bingol, E. (22). Güneydoğu Anadolu'da Neolitik Dönem dikilitaş geleneği: Bağlamsal yaklaşımla karşılaştırmalı bir değerlendirme. Anadolu Araștırmaları-Anatolian Research, 25, 27-59

https://doi.org/10.26650/anar.2021.990953
öZ

Güneydoğu Anadolu Bölgesi'nin Neolitik Dönem yerleşimleri özellikle son yirmi beş yıldır kült yapıları ve simgecilik merkezli farklı teoriler üzerinden yoğun olarak incelenmiştir. İlk olarak Nevali Çori, sonrasında Göbeklitepe'nin keşfiyle birlikte bölgedeki araştırmaların merkezine yerleşen kült yapıları, dikilitaşlar ve kabartma motifler, din arkeolojisi açısından yenilikçi kuramsal tartışmaları da beraberinde getirmiştir. Bu çalışmanın ana konusunu Çanak Çömleksiz Neolitik Dönem içerisinde bir gelenek halini alan dikilitaşların arkeolojik bağlamlarından hareketle değerlendirmesi oluşturur. Değerlendirme kapsamında ilk olarak tüm yerleşim yerlerinde saptanmış olan dikilitaşlar ve üzerinde bulunan betimlemeler ayrıntılı olarak ele alınmıştır. Daha sonra dikilitaşların sahip olduğu özellikler yerleşmeler arası karşılaştırmalar yapabilmekiçin sayısal verilere dönüştürülmüş ve buradan elde edilen istatistiki sonuçlardan ve dikilitaşların arkeolojik bağlamlarından hareketle bütüncül bir yaklaşımla yeniden yorumlanmıştır. Dikilitaşlar üzerindeki tasvirlerin sembolik içeriğiyle arkeolojik bağlamları bir arada ele alındığında Güneydoğu Anadolu Çanak Çömleksiz Neolitik Dönem toplumlarının ritüel davranışlarına ışık tutacak niteliktedir. Fırat ve Dicle Bölgesi'nde ele geçen dikilitaşlar form, boyut ve tasvir anlayışı bakımından iki farklı geleneği yansıtmakta, her iki bölgenin özgün karakterinin göz ardı edilmemesi gerektiğine işaret etmektedir. Bu fark, aynı zamanda, ritüel ve inanç pratikleri açısından ayrışan düşünsel dünyaların varlığının göstergesidir. Bununla birlikte her iki bölgede de kült yapıları çoğunlukla yerleşim yerlerinin domestik mekânlardan ayrı, özel olarak seçilmiş bir alanında yer alır. Tüm bu yapıların sürekli yenilenmesi ve onarılması, dikilitaşların devşirme malzeme olarak tekrar tekrar kullanımı, binaların kullanım sonunda gömülmesi ortak özellikler olarak karşımıza çıkar. Dikilitaşlar üzerindeki eril ve yabanıl dünyadan ilhamını alan sembolizm ise özellikle Fırat Havzasında dikkat çekici bir özellik olarak tartışıımıştır. Aynı bölgede zamanla önce dikilitaşların boyutlarının küçülmesi, daha sonra tamamen yok olması Neolitik yaşam biçimindeki ekonomik ve ideolojik kırılmalara işaret edebilir.

Anahtar Kelimeler: Güneydoğu Anadolu, Çanak Çömleksiz Neolitik Dönem, Dikilitaş Geleneği, Kült Yapıları, Göbeklitepe 


\begin{abstract}
The last 25 years witnessed an unprecedented increase in the theoretical and empirical research on the southeast Anatolian Pre-Pottery Neolithic (PPN) period, focusing on cult buildings and ritual symbolism. The cult structures, pillars, and relief motifs, which became the center of research in the region with the discovery of Nevali Çori and Göbeklitepe, engendered novel theoretical discussions within the archaeology of religion. The main subject of this study is the evaluation of the stone pillars - which became a tradition in the PPN period-in terms of their archaeological contexts. This paper discusses the pillars and details and depictions etched on them, while compiling numerical data on their assessed features. All the stone pillars unearthed so far in archaeological excavations and surveys have been re-evaluated and reinterpreted from a holistic approach by considering the archaeological contexts as well as their structural features and relief depictions. Stone pillars provide ample information on the symbolism and ritual practices of the communities when assessed with their archaeological contexts and symbolic features as a whole. The stone pillars identified in the Euphrates and Tigris regions represent two different traditions in terms of form, size, and depiction, which indicate that these two regions need to be viewed as two unique and separate yet connected entities. This difference is an indication of unique symbolic and ritual practices that refer to distinct ideological worlds. However, in both regions, the cult and special buildings were mostly located in a specially selected area of the settlements, separate from the domestic features and architecture. In addition, the practice of constant construction and re-construction, the secondary use of pillars as architectural elements, and the subsequent burial of buildings when their use-life was completed are common characteristics observed in both regions. Masculine and wild faunal symbols typically characterize the pillars from the Euphrates Basin sites. The gradual shrinkage of pillar size and their subsequent disappearance at the Euphrates Basin sites may suggest that ideological and economical transformations were underway in Neolithic society.
\end{abstract}

Keywords: Southeast Anatolia, Pre-Pottery Neolithic Period, Pillar Tradition, Cult Buildings, Göbeklitepe

\title{
EXTENDED ABSTRACT
}

While research and fieldwork at the Pre-Pottery Neolithic (PPN) sites in Southeast Anatolia are still unfolding, this study focuses on the stone pillars found there as ritually charged elements within specially constructed buildings. This article compares and contrasts the structural, contextual, and compositional aspects of the stone pillars from the Euphrates and Tigris Basins dating back to the 10th and 9th millennia BCE. This contextual-comparative approach allows the production of quantitative and qualitative data on the yet unrecognized aspects of stone pillar tradition in the region. In a broader sense, this approach may inform archaeology of religion and cult as theoretical research agendas.

Stone pillars provide ample information on the symbolism and ritual practices of the communities when assessed holistically with their archaeological contexts and symbolic features. The stone pillars identified in the Euphrates and Tigris regions represent two different traditions in terms of form, size, and depiction, which indicate that these two regions need to be viewed as two unique and separate yet connected entities. In Southeast Anatolia, all the cult buildings were found at special locations within the sites separate from the domestic architecture. All the buildings were used, re-used, and re-organized before they were buried. However, there are pronounced differences between the stone pillars in the Euphrates (mainly Urfa) Region and those in the Tigris Region. For instance, all the PPN Tigris stone pillars were left undecorated, except for a few circular marks on some of the Gusir Höyük pillars. The anthropomorphic pillars with human depictions were found only 
at the Urfa sites, such as Nevali Çori, Harbetsuvan, and Göbeklitepe. In the Tigris Region, however, both Gusir and Hasankeyf provided evidence of ritual depositions of animal horn cores around the stone pillars, a practice not evident from the Urfa sites. Another difference is in the treatment of the buildings after their use-life. In Çayönü and Hasankeyf, both in the Tigris Region, the stone pillars were mostly broken as they were re-used as building materials. These buildings were buried with sterile soil. However, in the Euphrates sites, such as Göbeklitepe and Harbetsuvan, the buildings were buried with rubble and many impurities. All these differences are arguably a reflection of diverging perceptions toward cult and related ritual symbolism, practices, and performances in both regions.

The richness of the visual depictions at the Urfa sites allow for an interpretation in terms of the Neolithic religious conceptions. The animal figures on the pillars and their location within a cult building indicate an intention to interact with, or even control, nature and its beings and spirits. Specifically, the complexity of compositions with various animal species showing them in interaction may depict ancient creation and heroic myths of the communities. The contextual relation of human-like T-shaped pillars, their clear masculine references, and the animal reliefs on them may likewise be interpreted as symbolic manifestations of controlling and dominating the wild, aggressive animals. There is clearly a close symbolic relation between the hunter-gatherer individual and wild animals as part of a wider ideological world. 


\section{Giriş}

Güneydoğu Anadolu Bölgesi Çanak Çömleksiz Neolitik (ÇÇN) dönem kült yapılarında (Harita 1) görülen dikilitaşların kullanımı yalnızca mimari bir öğe değil aynı zamanda kabartma tasvir çeşitliliğiyle de dikkat çekici bir unsur olarak karşımıza çıkmaktadır¹. Neolitik Dönem tartışmalarına dair farklı kuramsal tartışmaları da beraberinde getiren avcıtoplayıcı karakterdeki toplulukların bu tarz anıtsal yapılar inşa etmesindeki etkenler, ideolojik ve sosyo-ekonomik modeller kapsamında açıklanmaya çalışılmıştır (Cauvin, 2000; Hayden, 2015; Özdoğan, 2007; Schmidt, 2005; Türkcan, 2006). Diğer yandan, tasvir gruplarının yerleşimlere ve dönemlere göre dağılımları, evrelere göre gelişimleri gibi konular arkeolojik bağlamda geniş bir açıdan ele alınmamıştır.

Dikilitaş geleneği Güneydoğu Anadolu Bölgesi’nde Fırat ve Dicle Havzalarında yer alan Çanak Çömleksiz Neolitik Dönem yerleşmelerinde karşımıza çıkar. Şanlıurfa Bölgesi’ndeki şu ana kadar saptanmış olan yerleşimlerin çoğunlukla Harran Ovası'na hâkim tepelerde bulunması, ovadan geçen av hayvanlarının takibine ve avlanmasına imkân vermesi (Çelik, 2018) ve yapı inşası için gerekli olan hammaddeye kolay erişim sağlayan kireçtaşı platolar olması en başlıca neden olarak görülmektedir. Bununla birlikte Şanlıurfa şehir merkezinde yer alan Yeni Mahalle örneğinde olduğu gibi benzer özellikler sergileyen yerleşimler yalnızca platolarda olmayıp ovalık alanlarda da karşımıza çıkmaktadır.

Yukarı Dicle Bölgesi'nde şu ana kadar saptanmış olan yerleşim yerlerinde ele geçen dikilitaş örneklerine bakıldığında, az sayıdaki soyut tasvir örneği dışında Şanlıurfa Bölgesi’ne göre neredeyse tümünün bezemesiz olduğu görülmektedir. Form ve boyut olarak da bölgesel farklılıklar göze çarpmaktadır. Her iki bölge özelinde görülen farklılıkların kült ile ilişkili ritüel faaliyetler sırasında simgesel düşünce pratikleri açısından bir takım farklı algılamalar olduğunun yansıması olarak görülebilir. Arkeolojik araştırmalarda tespit edilen dikilitaşların bölgesel, kronolojik, bağlamsal olarak ayrıntılı değerlendirilmesi bu açıdan yapılacak çalışmalara da önemli bir veri kaynağı olacaktır.

Ayrıca sembolizmi merkeze alan tartışmalar, çoğunlukla yerleşimlerin sivil mimari unsurlarını yakın döneme kadar ikincil planda bırakırken, ağırlıklı olarak Göbeklitepe özelinde yürütülmüş ve dikilitaşlı yerleşimler yalnızca inanç ile ilişkili merkezler olarak kabul edilmiştir. Bu bakış; dikilitaşlı yapıların ele geçtiği yerleşimleri çoğunlukla sadece kült yapılarından oluşan ya da olası "hac" merkezleri (Watkins, 2014) olarak gören ve ne yazık ki arkeolojik olarak bağlamsal ve bölgesel değerlendirme bütünlüğünden yoksun bir tartışmanın odağına yerleştirmiştir. Bu yerleşimlerin sivil yapı örnekleri gibi yeni bulgular barındırması da yeni tartışmaları ve değerlendirmeleri beraberinde getirmektedir.

1 Bu makale, “Güneydoğu Anadolu Bölgesi Çanak Çömleksiz Neolitik Dönem Dikilitaş Geleneğinin Gelişimi ve Simgeciliğì" başlıklı yüksek lisans tezinden üretilmiştir. 
Kuşkusuz insan türünü diğer canlı formlarından ayıran önemli etkinlik alanı simgeler kullanma yeteneğidir (Renfrew ve Bahn 2017, s. 432). Simge, duyularla ifade edilemeyen bir şeyin yerine kullanılan somut nesne veya işaretlerdir. Dikilitaşlar üzerinde yer alan hayvan simgelerinin, dönemin topluluklarının dünya görüşlerini de oluşturan ve yansıtan önemli bir görüntü sunar. $\mathrm{Bu}$ anlamda, dikilitaşlar üzerinde betimlenen hayvan simgeleri ve bu simgelerin ritüel yapılardaki konumlandırılmaları da ele alınıp değerlendirilmiştir.

\section{Dikilitaşların Ortak Özellikleri: Kronoloji, Hammadde, Form ve Boyut}

Güneydoğu Anadolu Bölgesi’nde dikilitaşlı yapılara dair en erken bulgular MÖ 10 . binyılın başlarına tarihlendirilen Gusir Höyük (Karul, 2011), Hasankeyf (Miyake, 2016) ve Göbeklitepe'den (Schmidt, 2007a) gelmektedir. Göbeklitepe'nin II. tabakası ve Nevali Çori'nin Kült Yapısı III'ten anlaşıldığı kadarıyla dikilitaşların ÇÇNB evresinin sonuna doğru, yani MÖ 9. binyılın sonuna doğru azaldığı, MÖ 8. binyıldan itibaren devam etmediği görülmektedir (Bingöl, 2018, s. 4).

Dikilitaşların yapımında kullanılan malzeme istisnasız olarak kireçtaşıdır. Şanlıurfa Platosu'nda az kıvrımlı kireçtaşı ve yer yer bazalt kaynakları mevcuttur. Platoda yer alan kireçtaşlarından oluşmuş yüksek bir alan olan Tek Tek ve Susuz Dağları dikilitaşların yapımında kullanılan hammaddenin kaynağını oluşturur (Tunçdilek, 1971, s. 116).

Güneydoğu Anadolu Bölgesinde şu ana kadar saptanan dikilitaşlar, form olarak "T", ters "L" ve "I" biçimli olmak üzere üç farklı tip göstermektedir (Tablo 1). Bölgesel olarak bir ayrımın da görülebildiği dikilitaş buluntuları içerisinde, Yukarı Dicle Bölgesi'nde kazıları yapılmış olan Gusir Höyük, Çayönü, Hasankeyf Höyük ve Boncuklu Tarla yerleşim yerlerinde ele geçen dikilitaşların tümü "I" formunda olup henüz " $T$ ” formunda olan dikilitaş buluntusu mevcut değildir. Diğer bir yandan form olarak "T" ve ters "L" biçimli özellik sergileyen dikilitaşların tümü, şu ana kadar Şanlıurfa'nın Harran yöresine has bir özellik olarak karşımıza çıkmaktadır (Bingöl, 2018, s. 196).

Şimdiye kadar elde edilen verilerden dikilitaş boyutlarına bakıldığında (Grafik 1), Yukarı Dicle Bölgesi'nde ele geçen dikilitaşlar 1.5-3 metre arasında değişen yüksekliklere sahiptir. Bölgede yer alan Hasankeyf Höyük buluntusunun üst kısmının kırık olması nedeniyle yüksekliği bilinmemektedir (Miyake, 2016, s. 34). Gusir Höyük yerleşiminin her evresinde görülen dikilitaşlar 1.2 ile $1.5 \mathrm{~m}$ arasında değişen bir yüksekliğe sahiptir (Karul, 2013a, s. 94). Bölgenin bir diğer dikilitaş buluntusu veren Çayönü yerleşiminin ÇÇNB tabakasında ise Kafataslı Yapı (BM2a), Saltaşlı Yapı, Terrazzo Yapıları ve Meydan'da (Plaza) bütünlenebilir veya sağlam ele geçen dikilitaşlar boyut olarak 1.5-2.80 m arasında değişen yüksekliklere sahiptir (Özdoğan ve Özdoğan 1998, s. 592). Mardin'de yer alan Boncuklu Tarla'da "stelli bina" olarak tanımlanan yapı içinde bulunan dikilitaşlar ise $1.5 \mathrm{~m}$ yüksekliğe sahiptir (Kodaş, 2020, s. 25). 
Fırat Bölgesi dikilitaşlarının boyutlarında kronolojik olarak daha belirgin bir değişim söz konusudur. Dikilitaşlar, Çanak Çömleksiz Neolitik Dönemin A ve B evreleri arasında boyut bakımından farklılıklar gösterir. Şanlıurfa Bölgesi'ndeki dikilitaşlar hem taş ocaklarında çıkartılmaya hazır olarak bulunan taslak formlarla hem de yapı içlerinden bilinmektedir.

Bölgedeki bilinen en yüksek örnekler Göbeklitepe'nin III. tabaka yapılarından gelir. Göbeklitepe'nin ÇÇNA evresi ile ÇÇNB evresine geçiş aşamasına tarihlendirilen A, B, C, $\mathrm{D}$ ve $\mathrm{H}$ ve tabakaları belirsiz olan $\mathrm{F}$, G ve I yapılarında dikilitaşlar boyut olarak 1.90 ile 5.5 $\mathrm{m}$ arasında değişen yüksekliklere sahiptir (Grafik 2). Ancak genel bir kural olarak yapıların merkezinde konumlandırılmış olan dikilitaşlar, bunları çevreleyen dikilitaşlara nazaran daha yüksektir (Bingöl, 2018, s. 197).

Göbeklitepe'nin mutlak tarihlendirmesi yapılmış olan III. tabaka yapıları içinde en eski tarihi veren D Yapısı'nın merkezi dikilitaşlarının yükssekliği 5.5 m'dir. Merkezi dikilitaşları çevreleyen dikilitaşlar ise merkeze nazaran daha küçük boyutlu olup genel olarak 3 m'den büyüktür (Dietrich ve ark., 2013, s. 37-38). D Yapısı'ndan daha geç bir tarih veren C Yapısı'nın merkezi dikilitaşları ise 5 m yüksekliğindedir (Schmidt, 2010a, s. 249). Söz konusu dikilitaşların çevresinde yer alanların yükseklikleri ise 2 ile $3.50 \mathrm{~m}$ arasında değişir. Aynı yapının dikilitaş kalınlıkları ise 25 ile $50 \mathrm{~cm}$ arasında değişen ölçülere sahiptir. B Yapısı'nın merkezi dikilitaşlarının boyutları 3.40 ile 3.60 m'dir (Schmidt, 2007a, s. 128-129).

Göbeklitepe III. tabaka ile II. tabaka arasında geçiş evresine tarihlendirilen ve olasılıkla daha geç inşa edilmiş olan A Yapısı'nın merkez dikilitaşlarının yüksekliği ise 3.15 m'dir (Schmidt, 1998, s. 3). Daha küçük boyutlu olan çevre dikilitaşlar ise 1.70 ile $2.10 \mathrm{~m}$ arasında değişen yüksekliklere sahiptir (Bingöl, 2018, s. 197).

H Yapısı henüz tam olarak kazılmamasına rağmen açığa çıkartılan merkez dikilitaşlardan P51 numaralı dikilitaşın yüksekliği $2.70 \mathrm{~m}$, genişliği $1.26 \mathrm{~m}$ ve kalınlığı $52 \mathrm{~cm}$ 'dir. Açığa çıkartılan çevre dikilitaşlarının boyutları ise 2 ile $2.5 \mathrm{~m}$ arasında değişmektedir. Bu yapılarda ele geçen dikilitaşların boyutları, III. tabaka dikilitaşlarına kıyasla daha küçük boyutludur. I Yapısı'na ilişkin olarak henüz detaylı bir yayın yapılmaması nedeniyle yapıdaki dikilitaşların boyutlarına ilişkin şimdilik bilgimiz yetersizdir. F Yapısı'ndaki PXXXVII numaralı dikilitaşın ele geçen kısmının yüksekliği 1.70 m'den büyüktür. Aynı yapıdaki PXXXV numaralı dikilitaşın yüksekliği ise 2.15 m'dir (Dietrich, Notroff ve Schmidt 2015, s. 99-100; Schmidt, 2010a, s. 244).

Yuvarlak planlı yapılardan dörtgen planlı mimariye doğru bir geçişin olduğu Göbeklitepe'nin II. tabaka yapıları içinde şimdiye kadar yayını yapılmış olan toplam 43 adet dikilitaşın varlığı bildirilmiştir. Bu dikilitaşlarının ortalama yükseklikleri 1 ila 2 metre arasında değiştiği görülmektedir. Bu verilere dayanarak, Göbeklitepe'de dikilitaşların 
boyutlarının zaman içinde giderek küçülmüş olduğu görülür (Grafik 2). Bu duruma paralel olarak, yapıların boyutlarında da küçülme göze çarpmaktadır.

Göbeklitepe dışında, Şanlıurfa bölgesinde kazı çalışmaları sırasında dikilitaşlı yapıların bulunduğu yerleşimlerden biri de Nevali Çori'dir. Buradaki dikilitaşlı yapılar MÖ 8 . binyıla ait tabakalardan gelir. Kült Yapısı II'nin tüm olarak korunmuş iki adet dikilitaşın yükseklikleri 1.70 ile 1.95 m'dir (Hauptmann, 1993, s. 47-48). Kült Yapısı II ve III'de sağlam veya tümlenebilir olarak ele geçmiş dört adet dikilitaşın boyutu 1.70 ile $3.15 \mathrm{~m}$ arasında değişmektedir (Hauptmann, 2012a, s. 17-18).

Harbetsuvan Tepesi'nde şu ana kadar yüzeyde ve kazı çalışmalarında toplamda 36 adet dikilitaş açığa çıkartılmıştır. Bütün olarak tespit edilen dikilitaşın yükseklikleri 1.5 ile 2.05 m arasında değiştiği görülür (Bingöl, 2018, s. 162-169; Çelik ve Uludağ 2019, s. 337-356; Çelik ve T. Çelik 2020, s. 310).

Karahan Tepe'de tespit edilen dikilitaşlardan birisi taş ocağında bulunan ve taşınmak üzere kabaca işlenmiş haldedir. Söz konusu dikilitaşın yüksekliği $4.5 \mathrm{~m}$, genişliği ise 1.5 m'dir (Güler ve Çelik 2015, s. 85). Yerleşim yerinde in situ halde saptanan 266 adet dikilitaşın boyutları tam olarak bilinmemekle birlikte, yüzeyde ve kaçak kazılar sonucu kısmen açı̆̆a çıkarılmış olanların genişlikleri $90 \mathrm{~cm}$ ile $70 \mathrm{~cm}$, kalınlıkları $25 \mathrm{~cm}$ ile $20 \mathrm{~cm}$ arasında olup yükseklikleri ise yaklaşık 1.5- 2 m olarak ölçülmüştür (Çelik, 2005, s. 138).

Yüzey araştırmasında saptanan Sefer Tepe'deki dikilitaşların yükseklikleri $1.5-2 \mathrm{~m}$ arasında değişir (Tablo 1). Kalınlıkları 20 ile $30 \mathrm{~cm}$ arasında değişen dikilitaşların genişlikleri 50-70 cm'dir (Çelik, 2006, s. 24). Taşlı Tepe ve Kurt Tepesi yerleşim yerlerinde saptanan dikilitaşların yükseklikleri 1.5 ile $2.5 \mathrm{~m}$ arasındadır. Kalınlıkları 20-25 cm arasında değişen söz konusu buluntuların genişlikleri 50 ile $70 \mathrm{~cm}$ arasındadır (Çelik, 2015a, s. 319). Besta Faki Mevkii'de saptanan dikilitaş gövde kısmına ait parçanın genişliği yaklaşık olarak 70 cm'dir (Çelik, 2016, s. 416). Kocanizam'da bulunan dikilitaş gövdesine ait tek parçanın boyutu, kenarlarının kırık olması nedeniyle saptanamamıştır (Güler ve ark., 2012, s. 160). Ayanlar Höyüğü'nde henüz T-biçimli dikilitaş tespit edilememekle birlikte, dikilitaşlar için yapıldığı bilinen ortası oyuk kaide parçaları ele geçmiştir (Çelik, 2017, s. 362).

Göbeklitepe'nin III. tabakası dışında Şanlıurfa'da ele geçen dikilitaşlar yapıların mimari özellikleri ve diğer buluntu öğeleri ile ÇÇNB evresine tarihlendirilmektedir. Göbeklitepe, Nevali Çori ve Harbetsuvan Tepesi dışındaki bilgiler şimdilik yalnızca (Bingöl, 2018) yüzey buluntuları ile sınırlıdır². Yeni başlayan Sefer Tepe ve Karahan Tepe kazılarıyla birlikte dikilitaşların boyutlarına dair bilgiler daha tanımlayıcı olacaktır. Şimdilik yukarıda

22019 yılı itibariyle Karahantepe'de bilimsel kazılar Necmi Karul başkanlığında başlamıştır. Bir diğer kazı çalışması, 2021 yılı içerisinde kısa süreli yapılan Sefer Tepe ve Sayburç yerleşim yerleridir. Her üç yerleşim yerinin bulgularına dair bilimsel yayınlar henüz bulunmamaktadır. 
mevcut verilerden yola çıkarak, her iki bölge açısından dikilitaşların boyut ve form olarak birtakım farklı özellikler sergilediğini söylemek mümkündür. Örneğin; Şanlıurfa Bölgesi dikilitaşlarının kronolojik olarak giderek küçüldüğünü net olarak söyleyebiliriz. Yukarı Dicle için bu durum benzer bir görüntü sergilememektedir. Ayrıca her iki bölgede form olarak birbirinden farklı tasarıma gidildiği görülmektedir.

\section{Dikilitaşlar Üzerindeki Tasvirler}

Şanlıurfa Bölgesi'ndeki ele geçen dikilitaşların üzerinde yer alan tasvirlerin tamamına yakını kabartma bezemeli olup aynı zamanda zengin bir çeşitliliğe sahiptir. Göbeklitepe'nin III. tabakasına ait 39 adet dikilitaş üzerinde kabartma bezemeler bulunmaktadır (Bingöl, 2018, s. 304, Tablo 3). Bu sayı, şu ana kadar III. tabakada saptanmış dikilitaşların yarısından fazlasının kabartmalı olduğunu göstermektedir. ÇÇNB evresine ait II. tabaka dikilitaşlarında ise tasvirler büyük oranda azalır. Göbeklitepe dışında Nevali Çori, Harbetsuvan Tepesi, Yeni Mahalle, Karahan Tepe, Sefer Tepe, Kurt Tepesi ve Kilisik yerleşimlerinde az sayıda da olsa hayvan, el-kol, kravat ve şevron motifi kabartmaları (Tablo 1) görülmektedir.

Yukarı Dicle Bölgesinde şu ana kadar ele geçen dikilitaşlar üzerinde kabartma bezeme bulunmamıştır. Yalnızca Gusir Höyük’teki dikilitaşlardan birkaç örnek üzerinde kazıma bezeme izleri bulunmaktadır. Bu bezemeler birkaç küçük daire ve küçük delikler ile temsil edilmektedir (Karul, 2013a, s. 94).

\section{Hayvan Tasvirleri}

Dikilitaşlar üzerinde bulunan süslemeler içerisinde en yoğun tasvir grubunu hayvanlar oluşturur. Hayvan kabartmaları oldukça doğalcı bir biçimde betimlenmiş olup Erken Holosen faunasını yansıtır. Tasviri yapılan türler arasında ceylan, yaban eşeği, yaban domuzu, tilki, aslan, boğa, tavşan, kuşlar, yılan, örümcek ve akrep yoğunluk göstermektedir. Üzerinde hayvan tasvirlerinin yer aldığı dikilitaşlar, şu ana kadar yalnızca Göbeklitepe, Karahan Tepe ve taslak şeklinde bulunan boğa başının bulunduğu Sefer Tepe'de ele geçmiştir (Tablo 1).

Hayvan tasvirlerinin kronolojik ve yapılara göre dağılımına bakıldığında³ Göbeklitepe'nin D Yapısı içerisinde şu ana kadar toplamda 13 farklı türe ait hayvan motifi işlendiği görülür (Grafik 3). Sayısal olarak en yoğun olarak işlenen hayvanlar sırasıyla yılan, tilki ve kuş türleridir (Schmidt, 2007b, s. 156-157). Toplamda 31 adet bulunan yılanların ve 20 adet bulunan kuş türlerinin, bazı dikilitaşlar üzerinde kalabalık gruplar halinde tasvir edilmesi bunların sayısal olarak öne çıkmasını sağlayan bir unsur olduğu düşünülmelidir (Bingöl, 2018, s. 202). D Yapısı içerinde bulunan diğer türler ise sayısal çoğunluğuna göre sırasıyla, örümcek, akrep, boğa, koç, yaban domuzu, tavşan, aslan, ceylan ve yaban eşeği gibi

3 Göbeklitepe'nin tasvirlerine ilişkin sayısal veriler, yayınlardaki bilgilere dayanarak oluşturulmuştur. Detaylı veriler için bkz. Bingöl, 2018, Tablo 3-4. 
hayvanlardır (Peters ve Schmidt 2004, s. 211). Yapı içerisinde şu ana kadar toplamda 65 adet hayvan tasviri açığa çıkmıştır. D Yapısı'nda bulunan hayvan motiflerinde hâkim olan tür tilkidir. Merkezi dikilitaşların her ikisi üzerinde yer alan tilki motifi, yapı içerisinde toplamda yedi farklı dikilitaş yüzeyinde işlenmişstir. Merkezi dikilitaşların gövde kısmında yer alan üç adet tilki kabartmasının ikisinin işlendiği P31 numaralı dikilitaş üzerinde ayrıca bir adet boğa boynuzu motifi bulunmaktadır (Bingöl, 2018, s. 202).

Göbeklitepe'nin C Yapısı'nda bulunan türler arasında baskın olan motif ise yaban domuzudur. Sekiz farklı dikilitaş üzerinde betimlenmiş olan söz konusu hayvana ait tasvir sayısı toplamda 10 adettir. Hayvan çeşitliliği açısından türlerin D Yapısı'na göre azaldığı görülen yapı içerisinde, ördek, turna, tilki, boğa, tavşan, ayı (?) ve tanımlanamayan iki adet tasvir bulunmaktadır. Merkezi dikilitaşların birisinde (P37) tilki motifi yer alırken diğerinde ise boğa kabartması bulunmaktadır. Yapı içerisinde şu ana kadar toplamda 26 adet hayvan kabartması ele geçmiştir (Bingöl, 2018, s. 202-203; Schmidt, 2007b, s. 138-140).

C Yapısı'yla yaban domuzu arasında özel bir ilişki var gibi görülmektedir. Göbeklitepe'nin tüm yapılarında görülen toplam 12 adet yaban domuzu kabartmasının 10'u bu yapıda ele geçmiştir. Aynı zamanda şu ana kadar bulunan yedi yaban domuzu heykelinin altısı bu yapı içinde bulunmuştur (Schmidt, 2008a, s. 29-31; Schmidt, 2010a, s. 250). Yaban domuzu heykellerinin ele geçtiği konumlara bakıldığında bir düzenleme içinde yerleştirilmiş olabileceği akla yatkın gelir. İlk heykel yapının giriş kapısında bulunurken, ikincisi girişin hemen ardından yapının ikincil duvarı ile çevrelenmiş alanın girişe göre hemen solunda bulunmuştur. Diğer heykeller ise yapının birincil duvarı ile çevrelenmiş iç bölümde yapıya girişin hemen solunda bulunan P24 numaralı dikilitaşın yakınında, bu dikilitaşın tam karşısında bulunan kuzey duvarı bölümünde ve merkez doğu dikilitaşın hemen yakınında bulunmuştur (Schmidt, 2007b, s. 138-143).

B Yapısı hayvan tasvirlerine bakıldığında diğer yapılara nazaran az türde ve sayıda motif işlenmiştir. Yapıda üçer adet yılan ve tilki motifi bulunmaktadır. Tilkilerinden ikisi yapının merkez dikilitaşlarında yer alır (Schmidt, 2007b, s. 128-129). Toplam altı hayvan kabartmasının yalnızca iki tür ile temsil edilmesi, bu yapının diğer yapılara göre daha sade tasarlandığına işaret eder.

Göbeklitepe'nin II. tabakaya geçiş evresine tarihlendirilen A Yapısı'nda en fazla betimlenen tür toplamda 23 adetle temsil edilen yılandır. Bunlardan 22 tanesi yapının merkezi dikilitaşlarından birisi olan P1 numaralı dikilitaşın güneydeki dar ve doğudaki geniş tarafına işlenmiştir (Schmidt, 1998, s. 3). Yapının ikinci merkezi dikilitaşı olan P2 numaralı dikilitaş üzerinde ise tek bir tilki ve boğa başı kabartması bulunmaktadır (Driesch ve Peters 1999, s. 29). Tasvir edilen diğer iki hayvan türü farklı dikilitaşlar üzerine işlenmiş olan birer adet boğa ve turna motifidir. Yapı içerisinde toplamda 28 adet hayvan motifi bulunur (Bingöl, 2018, s. 203). 
Göbeklitepe'nin II. tabaka geçiş evresine tarihlendirilen H Yapısı içerisinde bulunan hayvan motiflerini; yılan, koç, kartal, ördek, boğa ve aslan oluşturmaktadır. Sayısal olarak toplamda 63 adet kabartmanın bulunduğu yapı içerisinde, en fazla kabartma, kompozisyon şeklinde işlenmiş geniş yüzünde 55, dar yüzünde ise dört tane olmak üzere toplamda 59 kabartma motifinin yer aldığı P56 numaralı dikilitaşta görülür (Dietrich ve ark., 2016, Fig. 10). Dikilitaşın dar olan ön tarafında $T$ başlığında bir, çene kısmında ise iki adet yılan ve bir adet koç/boğa başı işlenmiştir. Geniş ön yüzünde ise, 20 adet yılan, bir kartal, 24 adet ördek ve altı kedigil kabartması bulunmaktadır. Yapının merkez dikilitaşlarında birisi olan P51'in geniş yüzünde ise II. tabakaya ait olan Aslan Dikilitaşlı Yapı'da bulunan kabartma ile aynı tarzda işlenmiş olan aslan betimlenmiştir (Dietrich ve ark., 2016, s. 59-60).

F Yapısı'nda yer alan dikilitaşlar üzerinde hayvan kabartmaları grubunu hepsinden birer adet olmak üzere tilki, yaban domuzu, akbaba, köpekgil ve tanımlanamayan iki adet betim oluşturmaktadır. Kabartmalardan birinin tanımlanamadığı yapı içerisinde merkezi dikilitaşın üzerinde (PXXXVII) tilki motifi bulunmaktadır. Burada yer alan tilki motifi, D Yapısı'nın merkezi dikilitaşı olan P18'de görülen "kollar arasında tilki" motifine benzer şekilde betimlenmiştir (Schmidt, 2010a, s. 244).

Tabakaları belirsiz olan yuvarlak planlı yapılarda bulunan hayvan kabartmalarına dair bilgiler F Yapısı ile sınırlıdır. E Yapısı'na ait dikilitaş yalnızca oyuk şeklindeki kaidelerle sinırlidir (Schmidt, 2007a, s. 118).

Göbeklitepe'nin ÇÇNB evresine tarihlendirilen II. tabaka yapılarında hayvan motifleri sayısal olarak çok az görülmektedir (Tablo 1). Yayınlarda belirtildiği kadarı ile şu ana kadar II. tabakaya ait 43 adet dikilitaş üzerinde bulunan hayvan kabartmaları, bir akbaba ve iki aslan olmak üzere toplamda sadece üç adettir (Dietrich, Notroff ve Schmidt 2015, s. 98; Schmidt, 2008b, s. 420).

Yüzey araştırmalarında saptanan yerleşim yerlerinde ise hayvan motiflerine ait örnekler, şu ana kadar yalnızca Karahan Tepe ve Sefer Tepe'den bilinir. Karahan Tepe yerleşim yerinde henüz kazı çalışmaları yeni başlamış olması sebebiyle hayvan betimlemelerinin tür çeşitliliği ve sayısal dağılımları bilinmemektedir. Ancak Karahan Tepe'de yüzeyde kaçak kazılar sonucu açığa çıkmış olan karşılıklı iki dikilitaşın da yan tarafında kısmen görülebilen yılan kabartması bulunmaktadır (Çelik, 2003, s. 45; Çelik, 2005, s. 138-139). Üzerine kazıma tekniği ile yapılmış hayvan türleri ise, bir adet tavşanın başı ve ön ayakları, bir ceylanın uzun arka ayakları ve kuyruğu, son olarak memeli bir hayvana ait olduğu görülen fakat türü saptanamayan arka ayak betimlemeleridir (Çelik, 2003, s. 46). Hayvan tasvirinin dikilitaş üzerinde görüldüğü son örnek ise Sefer Tepe'de yüzey araştırmaları sırasında ele geçmiş olan tek parça ile sınırlıdır (Tablo 1). Bu parçanın üzerinde boğa başı kabartması bir taslak olarak bulunmaktadır (Çelik, 2005, Res. 49b). 


\section{İnsan Tasvirleri}

Bölge genelinde ele geçen dikilitaşlar üzerinde yer alan insan tasvirleri ve insana ait uzuvların (kol ve el) işlenerek antropomorfik görünümü verilen dikilitaşlar şu ana kadar yalnızca Şanlıurfa bölgesine has bir özellik gibi görülmektedir. Şanlıurfa dışında bulunan tekil bir örnek ise, "T" biçimli dikilitaşların en son şeklinin evrilmiş hali olarak görülen Adıyaman Kilisik heykelinden bilinmektedir (Hauptmann, 2012a, Res. 9a-d). Yukarı Dicle Bölgesi yerleşimlerinde bulunan dikilitaşların form olarak farklı oluşu ve üzerlerinde insan formuna işaret eden unsurların olmaması insan tanımının yapılmasını güçleştirmektedir.

Göbeklitepe'de bu tarz kabartma motifler D Yapısı'nda olduğu gibi merkez dikilitaşlar(P18 ve P31) üzerinde yer aldığı gibi F Yapısı'nın merkezi dikilitaşları (PXXXVI ve PXXXVII) ile birlikte bunları çevreleyen dikilitaş (PXXVI) üzerinde görülmektedir. C Yapısı'nın merkezi dikilitaşları üzerinde görülmeyen el ve kol kabartmaları yapıyı çevreleyen üç adet dikilitaş üzerinde görülmüştür. Bunlar P40, P46 ve P47 numaralı dikilitaşlardır (Piesker, 2014, s. 27).

Göbeklitepe'de dikilitaşlar üzerinde el ve kol motifleri ile bezenmiş örnekler dişında insan kabartmasının betimlendiği iki örnek bulunmaktadır. Bunlardan P43 numaralı dikilitaş (Notroff ve ark., 2017, Fig. 2) üzerinde bulunan insan tasviri, başı ve uzun boynu ile işlenmiş büyük boyutlu bir kuş motifinin hemen sağ tarafinda yer alan, başsız olarak gösterilmiş, kollarını havaya kaldırmış ve erekte olmuş fallusu ile betimlenmiştir (Schmidt, 2008b, s. 421). Diğer bir dikilitaş üzerinde betimlenmiş olan insan tasviri ise; F Yapısı'nda bulunmuş olan PXXV numaralı dikilitaş üzerinde görülmektedir. Dikilitaşın ön yüzünde daha önceki örneklerden farklı olan atkı bezeme yer alırken, gövdenin arka bölümünde ise bir insan motifi işlenmiştir (Schmidt, 2009, s. 165, Res. 4). Buradaki insan tasviri P43'ün aksine, başıyla birlikte cepheden betimlenmiştir.

Nevali Çori'nin kült yapılarının merkezi dikilitaşları olan ve Dikilitaş 1 ve 2 olarak numaralandırılan her iki dikilitaş üzerinde de kol ve el motifleri bulunmaktadır (Hauptmann, 1993, Res. 16; 2012a, Fig. 8). Benzeri bir örnek ise, Harbetsuvan Tepesi’nde yine kol ve el motiflerinin işlendiği 1 no'lu dikilitaş üzerinde de görülmektedir (Çelik, 2015b, Fig. 8; Bingöl, 2018, s. 164).

\section{Soyut Tasvirler}

Göbeklitepe yerleşim yerinde soyut tasvirler şimdilik yalnızca III. tabakaya ait C ve D yapılarındaki dikilitaşlar üzerinde görülür. Söz konusu soyut simgeler daire, yarım ay ve "H” biçimlidir (Schmidt, 2011, s. 214). Göbeklitepe dışında benzer örneklere şu ana kadar rastlanmamıştır. Ancak Gusir Höyük’te ele geçen dikilitaşların birkaç örneğinde bezeme izleri görülürken, bunlardan bir tanesinde üzerine kazınarak yapılmış birkaç küçük daire şekline rastlanmıştır (Karul, 2013b, s. 27). 


\section{Arkeolojik Bağlam}

Güneydoğu Anadolu Bölgesi’nin ÇÇN dönemi içinde kült ve/veya özel yapılar olarak tanımlanan yapılarda ele geçen dikilitaşların, arkeolojik bağlamı ile birlikte ele alındığında hem işlevsel hem de simgesel niteliğe sahip oldukları anlaşılmaktadır. Bıçakçı (2003, s. 406), ÇÇNA evresi ile başlayan dikilitaş kullanımının özellikle Orta ÇÇNB Nevali Çori Kült Yapısı, Geç ÇÇNB Çayönü Terrazzo Yapısı gibi kutsal amaçlı yapılarda işlevsellikten ziyade daha çok simgesel amaçlı kullanılmaya devam edildiği görüşündedir.

Büyük oranda mekân içi öğelerin bir bileşeni olarak düzenlenmiş olan dikilitaşlar, Çayönü Hücre Planlı Yapılar Evresinde ‘Meydan' örneğinde olduğu gibi mekân dışı olarak da kullanım görmüştür (Resim 1). Bu alanın belirli aralıklarla dizilmiş dikilitaşları barındırması, her yenileme evresinde 10-12 cm kalınlığındaki toprak tabanın dikkatle temizlenmesi, işlik alanının bulunmayışı, meydanın düzenleme şeklinin Göbeklitepe yuvarlak anıtsal yapıları andırması gibi özellikleri ile öne çıkmaktadır. Çayönü’ndeki “meydan” uygulaması bir anlamda dört duvar ile çevrili "özel kapalı mekânların” daha geniş ölçekli "üstü açık mekâna" aktarılması olarak görülebilir. Alan içerisinde işlik alanlarının bulunmayışı nedeniyle yalnızca günlük işlerde ya da törenlerde kullanılmış olabileceği düşünülmektedir (Erim-Özdoğan, 2007, s. 75-76; Özdoğan, A., 1995, s. 87).

Çayönü, yerleşimin en eski dikilitaşlarının bulunduğu "Saltaşıı Yapı"da, mekânın tam ortasına yerleştirilen iki adet dikilitaşın yapının payanda benzeri duvar çıkıntılarının tam hizasına gelecek biçimde, üçüncü dikilitaş ise yapının doğu duvarına koşut olarak hemen kuzeydoğu köşesine dikilmiştir (Özdoğan, A., 1994, s. 45-46). Bu yapının kuzeydoğusunda bulunan "Kafataslı Yapı"nın dörtgen planlı en eski yapı evresi olan BM2c'nin güney duvarı içinde (iki adet) ve doğu hücre dolgusunda yer alan tepeleri kırılmış dikilitaşların olasılıkla bir önceki evrenin BM1 evresi yapılarına aittir. Söz konusu her iki yapının da dikilitaşları yerlerinden sökülerek tepeleri kırılmış, ardından yapı içleri temiz toprak ile doldurularak terk etme töreninin bir parçası olarak "gömülmüş"lerdir (Erim-Özdoğan, 2007, s. 70-71).

Çayönü "Sekili Yapı"da bulunan kerpiç sekinin içinde yine tepeleri kırık olarak ele geçen iki adet dikilitaş (Schirmer, 1990, Fig. 11), "Saltaşlı Yapı"da olduğu gibi aynı yönde ve eşit aralıkla yerleştirilmiştir. Her iki dikilitaş arasında ise; koyu kırmızı renkte ince tanecikli dolgu bulunmaktadır. "Sekili Yapı”nın tabanı ise, özenle serilmiş küçük çakıl taşları ile karışık ince kumdan hazırlanmıştır. Bu tabanın altından yapının güneyine doğru uzanan bir kanal mevcuttur (Çambel ve ark., 1986, s. 44; Schirmer, 1990, s. 381; Özdoğan, A., 1994, s. 47). Terrazzo Yapısı'nda bulunan dikilitaşlar ise, Saltaşlı Yapı içerisindeki benzeri örneklerde olduğu gibi aynı yönde ve aynı aralıklarla yerleştirilmiştir (Schirmer, 1990, s. 381, Fig. 13). 
Gusir Höyük'ün neredeyse tüm yapı evrelerinde görülen dikilitaşlar ise, özenle biçimlendirilmiş ögütme taşının ya da özenle hazırlanmış bir altlığın içine yerleştirilmiştir. Belirli bir seviyeye kadar kilden bir yatağın içine yerleştirilmiş bir dikilitaş örneği de bulunmaktadır (Karul, 2013a, s. 94). Yerleşimin en üst evresinde bulunan ve çapı 10 m'yi bulan çukur tabanlı merkezi yapı içerisinde yer alan dört adet dikilitaşın (Resim 2) eş zamanlı olarak yerleştirilip yerleştirilmediği bilinmemektedir (Karul, 2013b, s. 27).

Gusir Höyük dikilitaşlarının etrafına törensel uygulamalarla ilgili olarak çok sayıda hayvan boynuzunun bırakıldığı görülmektedir (Karul, 2013b, s. 28). Duvar önlerinde ve dikilitaşların etrafında yer alan, olasılıkla ritüellerle ilişkili olabilecek kafatasları yabani koyunlara aittir (Karul, 2013b, s. 28). Törensel uygulamalar açısından bir diğer örnek olarak mekân içlerinde taban altlarında insan gömütlerinin varlığıdır (Karul, 2013a, s. 91). Uygulamaya dair benzer örnekler, Hasankeyf Höyük’te de mevcuttur (Maeda, Hongo ve Tanno 2016, s. 44-45).

Hasankeyf Höyük dikilitaşı, kenar uzunlukları 9 m’yi bulan ve oldukça büyük bir yapı olan 3 no’lu yapının (Resim 3) kuzeybatısında ve geniş yüzü yapının doğusuna bakacak şekilde yerleştirilmiştir. Yapıda farklı seviyelerde üç kez taban düzenlemesi yapılmıştır. Üst kısmı tamamen kırık olan dikilitaş, yapıya ait üçüncü tabana yerleştirilmiş, 30-40 cm'lik bir dolgunun ardından ikinci taban düzenlemesi sırasında ise bilinçli olarak kırılmış, geri kalan kısmı ise taban altına gömülmüştür. Duvarı taşla örülmüş bir çukur ve kilden yükseltilmiş bir platform yine bu yapı içerisinde bulunmaktadır (Miyake, 2016, s. 29). Yapı içinde bulunan dikilitaşın geniş yüzünün hemen bitişiğinde ritüel faaliyetler sırasında kullanıldığı düşünülen ortasında derin bir oyuk bulanan taş blok yerleştirilmiştir (Resim 4). Yanı sıra yapı içerisinde toplamda 30 adet gömüt çıkmıştır. Tüm bu bulgular birlikte ele alındığında binanın törensel amaçlı inşa edildiği ve yine törensel faaliyetler için ortaklaşa kullanıldığı önerilmektedir (Miyake, 2016, s. 34).

Boncuklu Tarla'da ÇÇNA-ÇÇNB geçiş evresine tarihlendirilen yerleşimin 4. tabakasında bulunan dikdörtgen formda ve yaklaşık olarak 2 metre bir derinliğe sahip çukur içerisine gömülü Kamu Binası'sının (Stelli Bina) merkezinde simetrik bir şekilde yerleştirilmiş olan dört adet dikilitaş bulunur (Resim 5). Bunlar Yukarı Dicle Havzası'na özgü sade ve düz formdadır. Binanın yenileme geçirmiş eski ve yeni duvarın olduğu kısımda tahrip olmuş kısa bir seki ya da platform yer alır. Yeni duvarın kuzey ucunda çok küçük ölçülerde derin bir niş açığa çıkartılmıştır. İçi sıvalı niş içinde herhangi bir buluntu ele geçmemiştir. Diğer yandan, binanın dolgusu içinde çok sayıda yontmataşlar, kemik aletler ve taş parçaları ortaya çıkmıştır. Binanın etrafında yuvarlak veya oval formda olan konutlar yer alırken, bahsedilen konutlar içerisinde mezarlar, ögütme taşları, havanelleri ve ocaklar gibi kamu binasında bulunmayan türde unsurlar yer almaktadır (İpek ve Çiftçi 2020, s. 220-222). 
Yine Orta ÇÇNB'ye tarihlendirilen 2. tabakada ise yaklaşık 15x13 metre boyutlarında “Terrazzo Binası” ortaya çıkarılmıştır. Yapının içinde çatıyı taşıdığı düşünülen dört ayrı dikilitaşın tarımsal tahribattan dolayı sadece yuvaları bulunmaktadır. Terrazzo Binası'nın batısında konut yapıları, doğusunda ise silolar yer almaktadır (Kodaş, 2018, s. 10-11).

Örneklerin ve mekânların çeşitliliği nedeniyle daha kapsamlı bakılması gereken Göbeklitepe'de; merkez dikilitaşların yönelimleri geniş yüzleri birbirine bakacak şekilde, yan dar yüzlerinin ise mekân girişine doğru yöneltilmiş şekilde düzenlendiği görülmektedir. Göbeklitepe III. tabaka yapılarında genel olarak büyük çoğunluğu anıtsal boyutlarda ve ortalama yükseklikleri 3 m'yi, ortalama ağırlıkları ise 10 tonu bulan dikilitaşlar, söbemsi veya yuvarlak planlı yapıların duvarlarına simetrik olarak yerleştirilmiştir (Schmidt, 2000, s. 31-32). Merkezi dikilitaşların tümü yerleşimin güneydoğu doğrultusunda konumlandırılmıştır (Schmidt, 2010b, Fig. 2). Şu ana kadar yalnızca F Yapısı'nda bu durum merkez dikilitaşın güneybatı yönüne doğru olan yönelimi nedeniyle farklı görünmektedir (Schmidt, 2010a, s. 244).

Göbeklitepe yapılarının taban döşemelerinde; yerleşim en erken tarihlerini veren C, D ve E yapılarının, doğrudan anakaya üzerine inşa edildiği görülmektedir. Kaya tabanları genel olarak özenle düzlenmiştir (Notroff ve ark., 2015, s. 54-55). Anakaya üzerine inşa edilmiş Göbeklitepe C Yapısı'nın güneybatısındaki iç halka duvarının hemen arkasında bulunan P11 ile P12 dikilitaşları arasında ikinci bir 'teras duvarı' ile dar bir şerit halinde sınırlandırılmış olan terrazzo taban örneği tespit edilmiştir (Piesker, 2014, s. 36). Göbeklitepe'nin B ve F yapılarında ise, taban döşemesinin Çayönü, Nevali Çori örneklerinde olduğu gibi terrazzo tabanlı olduğu görülmektedir (Dietrich, Notroff ve Schmidt 2015, s. 99). Göbeklitepe II. tabaka yapılarında da çoğunlukla benzeri taban düzenlenmesi örnekleri görülmektedir. Bu tabakaya ait Güneydoğu alandaki dörtgen ve trapez planlı, her biri üçer odadan oluşan altı adet mekân sıralamalarının (A-F mekânları) tabanları aynı teknikle döşenmiştir (Schmidt, 2000, s. 30).

Göbeklitepe'nin batı platosunda yer alan doğrudan anakaya üzerine inşa edilen E Yapısı'nın da tabanı dikkatlice düzeltilirken yapının ortasında $\mathrm{C}$ ve $\mathrm{D}$ yapılarında olduğu gibi podyum benzeri iki adet dikilitaş kaidesi bulunmaktadır (Schmidt, 2007a, s. 118). C Yapısı'nın merkezi dikilitaşlarında görülen örnekte dip kısmının kaide oyuğu içine, küçük taşlar ve balçık yardımı ile sıkıştırılarak yerleştirildiği belgelenmiştir (Schmidt, 2011, s. 212, Res. 2-3).

Yapıların giriş yerlerine dair bulgular, Göbeklitepe'nin A, B, C, E ve H yapılarında ve II. tabakaya ait Aslan Dikilitaşlı Yapı'sından bilinmektedir. Göbeklitepe'nin F, G ve I yapılarına ilişkin kazıların tamamlanması nedeniyle aynı tasarıma gidilip gidilmediği şimdilik bilinmemektedir. A Yapısı'nın apsidal bölümünün tam karşısında bulunan duvarın ortasına yerleştirilen "U”" şeklinde (Schmidt, 2000, s. 21) yekpare bir taş, Türkcan (2006, s. 89) tarafından A Yapısı'nın girişini oluşturabileceği şeklinde yorumlanmaktadır. B Yapısı'nın giriş yeri, duvar üstüne hafifçe kuzeye doğru dikey olarak yerleştirilmiş halde bulunmuş 
üzerinde bukranion ve açıklık kısmının etrafında iki tilki motifi yer aldığı kapı açıklığıdır (Resim 6). Pencere biçimli in situ halde bulunan bu kapı açıklığı, düzenlenişi bakımından ilk örneğini oluşturmaktadır (Schmidt, 2012, s. 324).

Eş merkezli en az üç çevre duvarına sahip olan Göbeklitepe C Yapısı'nın en dışta çember oluşturan geniş bir duvar örgüsü güneye doğru galeri şeklinde uzanırken, ön kısmı ' $U$ ' şeklinde işlenmiş yekpare bir taş blok ile bitmektedir. Bu alanın ise C Yapısı'nın yapı girişi olarak düzenlendiği anlaşılmaktadır (Schmidt, 2007b, s. 143). Göbeklitepe H ve E yapılarının girişlerine baktığımızda ise; C Yapısı'ndaki merdivenli girişe benzer bir örnek yerleşmenin kuzeybatısında bulunan H Yapısı'nda karşımıza çıkar (Dietrich ve ark., 2016, s. 58). E Yapısı'nın güneyinde girişin hemen yamacında, her biri yaklaşık $32 \mathrm{~cm}$ çapında ve 3 cm derinlikte olan delikler, Piesker (2014, s. 48) tarafından yapının merkez eksenine simetrik olarak düzenlenmiş ahşap bir kapı için tasarlanmış olabileceği şeklinde yorumlanmaktadır.

Göbeklitepe II. tabakaya ait Aslan Dikilitaşı Yapı'nın doğusunda hafifçe yükseltilmiş olan bir sekiye çıkan, tek basamaklı içine dikilitaşların yerleştirildiği merdivene benzeyen bir yapı bulunmaktadır (Schmidt, 2007b, s. 263).

Nevali Çori'nin Kült yapıları I. Evre'den itibaren yerleşimin yer aldığı terasın kuzeybatı tarafında yer alırken (Resim 7), yerleşimin batı kısmındaki konut yapılarına göre daha uzağa inşa edilmiştir (Hauptmann, 2011, s. 95). Nevali Çori kült yapısının mekânsal olarak, üst üste aynı yerde inşa edilmesi diğer bir deyişle her evrede konumunu koruması, bu yapıların inşa sürecinde yer seçiminin bilinçli bir seçim olduğu ve kült faaliyetler için ayrılan alanın, yerleşimin sonuna kadar aynı yerde korunmak isteğini göstermektedir (Hauptmann, 2007a, s. 97). Aynı zamanda yapı içlerinde Göbeklitepe örneğinde olduğu gibi, günlük kullanıma dair buluntulardan ziyade heykel gibi kült işlevi olduğu düşünülen nesneler ya gömülmüş ya da duvar yapılarında devşirme malzeme olarak kullanılmıştır. Nevali Çori'nin bir önceki evreye ait kült yapısının heykelleri, yapı içinde devşirme olarak kullanılırken, en geç evreye ait (Kült Yapısı III) kült yapısında, Kült Yapısı II’ye ait olduğu düşünülen çeşitli kireçtaşı yontular ve dikilitaş parçaları da yapının duvarlarında ve sekilerde devşirme olarak özenle kullanılmıştır (Hauptmann, 1993, s. 47).

Nevali Çori'de kült yapıların tabanı kireç harcıyla inşa edilen kalın bir terrazzo tabana sahiptir (Resim 8). Geniş ve tek odalı, yarı yarıya ya da tamamen toprağa gömülü olarak inşa edilen bu yapılar, duvarı boyunca uzanan taş sekiler ve özenle hazırlanmış terrazzo tabanlar gibi özellikleriyle konut yapılarından ayırt edici özellikler taşımaktadır (Hauptmann, 2007b, s. 141-142). Bahsedilen yerleşim yerleri dışında, Yeni Mahalle'de ÇÇNB dönemine tarihlendirilen kesit içinde toplam dört adet terrazzo taban ortaya çıkarılmıştır (Çelik, 2005, s. 93). Bir diğer terrazzo taban örneği ise, Taşlı Tepe yerleşim yerinde yapılan yüzey araştırmaları sırasında bulunmuştur (Güler ve ark., 2013, Fig. 3). 
Harbetsuvan Tepesi'nde ele geçen in situ dikilitaşlar, yap1 merkezinde yer alan tek veya karşılıklı iki dikilitaş şeklinde düzenlenmiştir. Az sayıda açı̆̆a çıkan duvar örgüsü içine yerleştirmiş örnekler de mevcuttur. Merkez dikilitaşların, yüzeyde açığa çıkan üst bölümlerinden anlaşıldığı kadarı ile dar ve geniş kesimlerinin belirli bir uygulama dâhilinde aynı yöne doğru konumlandırılmadığı görülmektedir (Bingöl, 2018, s. 225). Yerleşim yerinde dikilitaş içermeyen, buluntulardan depolama alanı olarak kullanım gördüğü düşünülen hücre planlı sivil mimari örnekleri de saptanmıştır (Çelik ve Tosyagülü Çelik 2020, s. 312-313).

K-11 açmasında yer alan Locus 3 numaralı yapı merkezinde üst kısmı tahrip edilmiş kabartmasız bir adet dikilitaş ele geçmiştir. Dikilitaşın dar olan bölümü kapı açıklığının bulunduğu duvara doğru bakar şekilde konumlandırılmıştır. Yapının taban döşemesinde üç evreli bir işlem yapılmıştır. İlk olarak anakaya üzerine yaklaşık $30 \mathrm{~cm}$ 'lik bir taş moloz içeren toprak dolgu, ardından taş plaka döşemesi, son evre de ise taş döşeme ile tabanın düzenlendiği belirtilmiştir. Bahsedilen yapıya ait giriş kapısı ise, yapının güneybatı ve güneydoğu duvarının kesiştiği alanda, güneybatı duvarının köşesinde yer almaktadır (Resim 9). Giriş yeri lento şeklinde kırık dikilitaş parçaları ile yapılmıştır. Kapı açıklığının yüksekliği yaklaşık 50 cm'dir (Bingöl, 2018, s. 224; Çelik ve Uludağ 2019, s. 340).

Harbetsuvan'da K-5 açmasında açığa çıkan karşılıklı iki dikilitaşın merkezde yer aldığı büyük boyutlu yapının güney duvarında yine giriş ve niş açıklığı bulunmaktadır (Resim 10). Yapı merkezindeki dikilitaşların dar yüzlerinin değil, geniş yüzlerinin girişe doğru bakması Harbetsuvan'da kendi içinde farklı tasarımların var olduğuna işarettir. Bahsedilen yapının, güneyde yer alan D14 numaralı dikilitaşın kaide kısmı ve hemen yakınında, yine K-11'deki yapıda olduğu gibi mekân ortasındaki dikilitaşın hemen önünde olasılıkla ritüel esnasında kullanılan ortasında oyuk bulunan in situ taş ele geçirilmiştir. Dikilitaş ise kaide üzerindeki mevcut durumu, alt kısmının geniş yüzünün ön tarafından öncesinden kırıldığ1 ve kırık kısmı yere doğru ayakta tutulması ise taş dizileri ile desteklendiği göstermektedir. Bu da söz konusu dikilitaşın daha farklı bir evreye ait yapıdan devşirildiğini, ikincil kullanımda ise yeniden düzenlendiğini göstermektedir (Çelik ve Uludağ 2019, s. 343-344).

\section{Değerlendirme}

Güneydoğu Anadolu Bölgesi'nde şu ana kadar saptanan dikilitaşlar T, ters L ve I biçimli olmak üzere üç farklı tip göstermektedir. Şanlıurfa bölgesinde şu ana kadar saptanmış olan dikilitaşlar T ve ters L biçimli olarak karşımıza çıkmaktadır. Ters L biçimli dikilitaş örnekleri Nevali Çori, Göbeklitepe ve Harbetsuvan Tepe'den ele geçmekle birlikte söz konusu yerleşmeler de dâhil olmak üzere şu ana kadar saptanan, Hamzan Tepe, Sefer Tepe, Karahan Tepe, Kurt Tepesi, Yeni Mahalle ve Taşlı Tepe gibi yerleşim yerlerinin tümünde ele geçen dikilitaşlar "T" formuna sahiptir4.

4 Kocanizam ve Besta Faki yerleşim yerlerinde dikilitaşlar, gövde kısımlarından kırık parçalar olarak ele geçtiği için formları net olarak tanımlayıcı değildir. Bununla birlikte T biçimli dikilitaşlarla benzerlik taşımaktadır. 
Yukarı Dicle Bölgesi’nde Gusir Höyük, Çayönü, Boncuklu Tarla ve Hasankeyf Höyük yerleşim yerlerinde ele geçen dikilitaşlar "I" biçimli olup bölge dâhilinde "T" formunda dikilitaş buluntusu veren yerleşim şimdilik mevcut değildir. Bu durum teknolojik, ideolojik ve kültürel olarak bölge özelinde görülen farklılıkların net bir göstergesi olarak karşımıza ç1kmaktadır.

Tasvir anlayışında da, iki bölge farklı görüntüler sergilemektedir. Gusir Höyük örnekleri dışında Dicle Bölgesi dikilitaşlarının neredeyse tümü bezemesizdir. Ancak; Şanlıurfa Bölgesi'nde ise tersi bir durum söz konusu olup dikilitaşlar üzerinde yoğun simgesel tasvir betimlemeleri görülmektedir. Form ve bezeme anlayışında görülen farklılıkların kült ile ilişkili olarak ritüel faaliyetler sırasında inanç ve uygulamada simgesel bir takım farklı algılamalarrın yansımaları olarak görülebilir.

Şanlıurfa'da bulunan dikilitaşların boyut gibi özelliklerinin yanı sıra, tasvirlerin sayısal dağılımları da evrelere ve yapılara göre farklılık sergilemektedir (Grafik 3). ÇÇNA'dan ÇÇNB'ye kadar birtakım dönüşümler yaşayan simgesel tasvirlerin Göbeklitepe özelinde erken evreden başlayarak geç evreye doğru azaldığı görülmektedir. Yaklaşık 20’ye yakın farklı türdeki hayvan betimlemelerin üzerinde işlendiği ve şu ana kadar saptanmış 211 adet hayvan kabartması (Bingöl, 2018, s. 306, Tablo 5), Göbeklitepe'nin ÇÇNA evresine ait dikilitaşları üzerinde bulunmaktadır.

Göbeklitepe özelinde hayvan tasvirlerinden tilki ve boğa, yuvarlak planlı yapıların ortak bir simgesi gibi görülmektedir. A, C ve F Yapısı'nın merkezi dikilitaşlarından birisinde, B ile D Yapısı'nın merkez dikilitaşlarının her ikisi üzerinde görülen tilki motifi simgesel açısından önemli olmalıdır. Yılan motifleri kadar sıklıkla karşılaşılan tilki motiflerinin neredeyse tamamı erkeklik organı ile ön ayakları havaya kalkık ve keskin dişleri görünür şekilde betimlenmiştir. Sayısal olarak en yoğun betimlendiği D Yapısı'nın her iki merkez dikilitaşının ön yüzünde ellerin birleştiği kemer tokasının hemen altında post şeklinde sarkan tilki postu betimlemesi bulunmaktadır. B Yapısı merkez dikilitaşlarının her ikisinde ve yapıya ait pencere biçimli girişin üzerinde tilki ve boğa tasvirleri yer almaktadır. ÇÇNB'ye ait II. tabaka yapılarında ise benzer bir durum görülmediği gibi tilki ve boğa betimi de bulunmamaktadır.

Tilki; Levant Epipaleolitik ve Avrasya Üst Paleolitik Çağ avcıları açısından da önemli bir anlama sahiptir. Ürdün'de bulunan Uyun al-Hammam mağarasında insan gömütünün yanında tilki kemiklerinin yer aldığı saptanmıştır (Maher ve ark., 2011). Üst Paleolitik Çağ'da Neuwied Havzası'nda yer alan Gonnersdorf buluntu yerinde ve Rusya'daki Sungir gömütlerinde olduğu gibi aynı zamanda tilki dişleri delinmiş, özellikle hayvanın köpek dişi tak1 ve kolye olarak kullanılmıştır (Clark, 1980, s. 115-129; Mitten, 1998, s. 200). Öldürülen hayvanların dişlerinin takı amacıyla kullanılması, avcının hayvanın akıl ve kurnazlığının da kendisiyle özdeşleşmesinin garanti altına alınmak istenmesidir (Schmidt, 2007c, s. 39). D 
ve F Yapısı'nın merkezi dikilitaşlarında görülen kollar arasında tilki motifi ile aynı zamanda bahsedilen hayvana ait kemiklerin de yerleşimin dolgusunda oldukça yoğun görülmesi (Schmidt, 2007b, s. 221), peştamal olarak tilki postunun betimlenmesi, tilkinin ritüeldeki rolünün önemine dair bir görüntü sergilemektedir.

Aslan ve akbaba gibi iki farklı türdeki hayvan kabartmasından bulunduğu ÇÇNB evresinde ise yalnızca üç adet tasvir örneği görülmektedir. Şanlıurfa Bölgesi’nde Göbeklitepe'nin II. tabakası ile çağdaş olduğu belirtilen diğer tüm yerleşim yerlerinde tasvir örnekleri birkaç sayı ile temsil edilmektedir. Söz konusu yerleşim yerlerine dair bilgilerimizin yalnızca yüzey araştırmaları ve kaçak kazılar sonucu açığa çıkmış olan dikilitaşlar ile sınırlı olduğu da dikkate alınmalıdır.

Göbeklitepe özelinde kronolojik olarak göze çarpan bir diğer olgu ise dikilitaşların boyutlarında görülen küçülmelerdir. A, B, C, D ve H yapılarının dikilitaşlarında bu durum kendini net bir şekilde göstermektedir (Grafik 2). En eski tarihi veren D Yapısı'nın merkez dikilitaşları daha büyük boyutlu iken, sırasıyla daha geç tarihlendirmeyi veren yapılarda eskiden yeniye doğru yavaş yavaş küçülme göze çarpmaktadır.

Güneydoğu Anadolu Bölgesi genelinde ele geçen dikilitaşlar üzerinde yer alan insan tasvirleri ve antropomorfik görünümü verilen dikilitaşlar ise Nevali Çori, Harbetsuvan Tepesi ve Göbeklitepe'den bilinen örneklerden anlaşıldığı üzere şimdilik Şanlıurfa bölgesine has bir özellik olduğu görülmektedir. Şanlıurfa dışında bulunan bir tekil örnek ise, T biçimli dikilitaşların en son şeklinin evrilmiş hali olarak görülen Adıyaman Kilisik heykelinde görülmektedir. Şanlıurfa Bölgesi'nde ele geçen dikilitaşlarda bulunan antropomorfik tasvirlerinin ÇÇN dönemi içerisinde tek bir evreye has bir özellik olmadığı görülmektedir. Bununla birlilte el-kol motifli dikilitaş örnekleri, Göbeklitepe'nin C ve F Yapısı'nda ve II. tabaka Aslan Dikilitaşlı Yapı'daki örneklerden bilindiği şekli ile yalnızca yapıların merkezi dikilitaşlarına özgü bir durum olmadığı da anlaşılmıştır.

Dikilitaşlı yapıların yerleşim yerlerindeki konumlarına dönük olarak elde edilen sonuçlarda, genel olarak yerleşim içinde bulunan konutlardan ayrı bir alanda inşa edildiği görülmüştür. $\mathrm{Bu}$ anlamda, kült ve yaşamsal alanlarının yerleşim içinde genel olarak birbirinden ayrıldığı anlaşılmaktadır. Çayönü örneğinde görülen dikilitaş barındıran anıtsal kült yapılarının, yerleşim yerinin doğu kesiminde konutlarla birlikte inşa edildikleri de görülmüştür. Ancak Çayönü örneğinde söz konusu yapıların her tabakada yerleşimde meydan olarak tanımlanan alanı çeviren yerleşimin doğu kesiminde inşaa edilmeleri bu alana özel bir anlam yüklendiğini ortaya koymaktadır (Özdoğan ve Özdoğan 1998, s. 592). Yine aynı yerleşim yerinde ele geçen dikilitaşların yalnızca yapı içlerinin birer bileşeni olarak değil, aynı zamanda meydan olarak adlandırılan alanda yapılardan bağımsız, belirli bir düzen ve anlayışla yerleştirildiği anlaşılmıştır. 
Mekânın iç düzenlenmesinde görülen önemli bir özellik ise, Göbeklitepe, Çayönü, Nevali Çori ve Gusir örneklerinden de bilinen sekilerin varlığıdır. Kült yapılarda sekilerin kullanım örnekleri Çayönü’nde olduğu gibi yapının kamusal karakterini ortaya koyan en önemli öğedir. Diğer bir yandan dikilitaşların inanç sistemi ile ilişkili olarak ritüel faaliyetler sırasında kullanıldığı düşünülebilecek Gusir ve Hasankeyf Höyük dikilitaşlarının etrafına çok sayıda hayvan boynuzunun bırakılması, Hasankeyf, Harbetsuvan Tepesi ve Göbeklitepe'de görülen dikilitaş yanında ortasında derin bir oyuk bulunan taş blok yerleştirilmesi uygulamasıdır.

Tartışılan bir başka olgu ise yapıların terkedilme veya gömülmesi sorunudur. Yapıların “gömülmesi”nde çeşitli bulgulara dayanarak belli aşamaları izlediği görülmektedir: Öncelikle yapı temizlenir, ardından bazı bölümleri tahrip edilir, dikilitaşlar ise kırılıp yere yatırılır ve bazı eşyalar ise hediye olarak bırakılır. Doldurma ya da "gömme" aşmasında ise, bazen yapının bilinçli olarak yakıldığı ve yanık dolgusuyla ya da temiz (elenmiş) toprakla doldurulduğu görülür (Schmidt, 2009, s. 165-171, Fig.75-79; Erim-Özdoğan, 2007, s. 71). Çayönü ve Hasankeyf örneğin görülen dikilitaşların kırılıp yere yatırılması, sonraki evrede üzerinin doldurulması örneği bugünkü bulgulara göre Fırat Bölgesi'nde bulunan Göbeklitepe ve Harbetsuvan yerleşimlerinde bu geleneğin biraz farklı olduğunu göstermektedir. T-biçimli dikilitaşlar burada oldukları gibi bırakılmış ve yapıların içi, elenmemiş, taşla karışık toprak molozla doldurulmuştur (Bingöl, 2018, s. 226).

\section{Sonuç}

Güneydoğu Anadolu Bölgesi Çanak Çömleksiz Neolitik Dönem yerleşmelerinde bulunan kült yapılar ve bu yapılarla ilişkili dikilitaşlar, bölgenin Neolitik dönemine ilişkin olarak Dünya Prehistoryası içerisinde yürütülen birçok tartışmada üzerinde en çok durulan konulardan birisidir. Kült yapılar ve dikilitaşların simgesel muhtevası dönemin toplulukları açısından ekonomik anlamlarından öte derin sosyolojik ve psikolojik temellerini de içerdiği söylenebilir. Başka bir deyişle, Çanak Çömleksiz Neolitik Dönem’e ilişkin yerleşim yerlerinden elde edilen arkeolojik veriler incelenirken dönemin tüm ideolojik, kültürel, sosyal ve ekonomik dinamikleri, bir bütüncül anlayış içinde daha geniş bir çalışma üzerinden irdelenmesi gerekmektedir.

Fırat ve Dicle Bölgesi dikilitaşları form, boyut ve tasvir anlayışındaki belirgin farklılık ile iki ayrı geleneği temsil etttiği söylenebilir. Bununla birlikte, tüm yerleşim yerlerinde bulunan kült veya özel yapıların çoğunlukla yerleşim yerlerinin özel olarak seçilmiş belirli bir alanında yer aldığı görülmektedir. Tüm bu yapıların süregelen bir biçimde kullanılması, kullanımın sonunda ise gömülmesi ${ }^{5}$ ortak bir özellik olarak karşımıza çıkan bir unsurdur.

5 Göbeklitepe'de açı̆̆a çıkartılmış olan tüm yapılar Neolitik Dönem içinde bilinçli olarak doldurularak kapatılmıştır. Doldurulma işlemine dair humus ve kireçtaşı tortusu üzerinde yapılan tarihleme ve sediman analizleriyle bu durum belgelenmiştir. Dolgu malzemesi olarak, yumruk büyüklüğünde taşlardan oluşan Neolitik dolgu, Göbeklitepe'yi karakterize eden kabartma bezemeli T-biçimli dikilitaşların günümüze kadar tahribatını da engellemiştir (Schmidt, 2012, s. 320). 
Yapıların gömme faaliyeti görünüşe göre mimari inşa süreci kadar yoğun emek gerektiren bir uygulamadır. Ancak gömme faaliyetinin yoğun emek gerektiren süreci ve böylesine görkemli yapıların neden gömüldüğünü açıklamak güçtür (Peters ve Schmidt 2004, s. 183). Söz konusu işlem sırasında, "yapıların gömülmesi” geleneğine bağlı olarak eski yapıların üzerleri toprak serilerek gizlenmiş ve korunmuştur. Terk edilme esnasında yapı planın bir kısmının korunduğu eski yapıların üstüne, yine eski duvarların hizasının takip edilerek aynı planı izleyen ve benzer işlevde başka yapıların inşa edildiği görülmektedir.

Dikilitaşlar üzerinde betimlenen inançlarla ilişkili hayvan simgelerinin, avc1-toplayıcı toplulukların dünya görüşlerini de oluşturan en önemli simgesel unsur olduğu açıkça görülmektedir. Dikilitaşlar üzerinde betimlenen hayvan simgeleri ve bu simgelerin ritüel yapılar içerisindeki konumu, dönemin insan topluluklarının doğaüstü (ve doğal) dünya ile, bu dünyada yaşayan insan ve hayvan ruhları ile etkileşimde bulunma ve onu kontrol etme amacına dönük olarak yapılan bir girişim şeklinde değerlendirilebilir. Özellikle farklı hayvan türlerinin birbirleriyle etkileşim halinde betimlendikleri ve kompozisyon şeklindeki motiflerin bazılarının karmaşıklığı da göz önüne alındığında, söz konusu tasvirlerin eski sözlü geleneklere ait olan yaratılış veya kahramanlık mitlerini betimleyen anlatılar olabileceği şeklinde de yorumlanabilir. Ritüel faaliyetler esnasında dikilitaşların üzerinde görülen yoğun hayvan simgeciliğinin katılanları bir hayvan dünyası ile birlikte doğaüstü dünya içerisine çektiğine kuşku yoktur. Betimlenen insan tasvirleri çoğunlukla hayvanlar ile yakın ilişkide gösterilmektedir. Hayvan ve avcı toplayıcı insan grupları arasındaki bu ikili ilişki, dikilitaşlar üzerinde de en net görülen temalardan birisidir.

T-biçimli dikilitaşların insanı temsil ettiği görüşünden hareketle, simgesel olarak insanın hayvanlar üzerinde hâkimiyetinin vurgulandığı veya genel olarak vahşi, ölümcül, can alıcı hayvanların kontrol altına alınmasına dönük bir çabanın da simgesel ifade biçimini de yansıttığı düşünülebilir. Dikilitaşların doğal dünyayla bağlantılı olarak bu hayattan değil, doğaüstü bir dünyaya ait başka varlıkları da temsil edebileceği de göz önüne alınmalıdır. Ancak, her iki durumda da hayvan dünyası üzerinden doğaya egemen olma gibi bir durumu yansitmaktadir.

Özellikle Şanlıurfa'nın Göbeklitepe ve Karahan Tepe yerleşmelerindeki dikilitaşlardan bilinen yoğun hayvan simgelerinin en belirgin yönünün, sonradan evcilleştirildiğini bildiğimiz hayvanlar yerine yabani hayvanlar üzerine odaklanıldığg anlaşılmaktadır. Şanlıurfa Bölgesi'nde kült yapıları inşa eden toplulukların faunal ve botanik kalıntılarından anlaşıldığı üzere büyük oranda avcı-toplayıcı geçim ekonomisine dayalı bir yaşam tarzı sürmektedir (Dietrich, Notroff ve Schmidt 2015, s. 102-103; Wilcox ve Savard 2007, s. 432). Evcil hayvanlardan ziyade yabani bir karakter içermesi bu açıdan doğal görünen bir durum olarak anlaşılmalıdır. Hayvan kabartmalarının oldukça doğalcı bir biçimde betimlendiği ve dönemin faunasına karşılık geldiği anlaşılmaktadır. 
Üst Paleolitik mağara sanatında ve Levant Epipaleolitik dönem geleneğindeki hayvan simgeciliğine göre, Güneydoğu Anadolu ÇÇN dönemi hayvan simgeciliğinde belirgin bir değişim göze çarpar. Bu fark özellikle memeli hayvanların saldırgan olarak tasvir edilmesidir. Özellikle tasvirlerdeki tilki, aslan ve yaban domuzunun keskin dişleri görünür biçimde dişleri ile gösterilmesi buna örnek verilebilir. Bununla birlikte bahsedilen hayvan türlerinin neredeyse tümüyle sertleşmiş penisi ile eril vurguların ön planı çıkartılması dönemin insan ve hayvan bağlantılarının, yabanıl, tehlikeli aynı zamanda saldırgan (kızgınlı dönemlerinin?) ifadesi olarak değerlendirilebilir.

Şanlıurfa'da bulunan dikilitaşların sayısal dağılımları ve boyut gibi özelliklerinin yanı sıra, tasvir sayıları da kronolojik olarak evrelere ve yapılara göre farklılık sergilemektedir. ÇÇNA'dan ÇÇNB'ye kadar birtakım dönüşümler yaşayan simgesel tasvirlerin Göbeklitepe özelinde de görüldüğü gibi erken evreden başlayarak geç evreye doğru azaldığ1 ve dönemin sonuna doğru tamamen dönüşüm geçirdiği görülmektedir. Dikilitaşlar ve üzerine işlenen temalardaki bu değişimler ÇÇNA'da tamamen avcı toplayıcı karakterde olan toplulukların ÇÇNB itibariyle, çiftçilik ve hayvancılığga doğru ekonomik ve kültürel dönüşümü ile bağlantılı olmalıdır. Başka bir deyişı, üretim ilişkileri ve araçlarının değişmesiyle ideolojik dünyanın da değişmiş olması mümkündür.

Hakem Değerlendirmesi: Dış bağımsız.

Çıkar Çatışması: Yazar çıkar çatışması bildirmemiştir.

Finansal Destek: Yazar bu çalışma için finansal destek almadığını beyan etmiş̧ir.

Peer-review: Externally peer-reviewed.

Conflict of Interest: The author has no conflict of interest to declare.

Grant Support: The author declared that this study has received no financial support.

\section{Kaynakça/References}

Bıçakçı, E. (2003). Observations on the Early Pre-Pottery Neolithic Architecture in the Near East: 1. New Building Techniques. M. Özdoğan ve ark. (Ed.), From Villages to Towns, Studies Presented to Ufuk Esin, (pp.385-413). İstanbul:Arkeoloji ve Sanat Yayınları.

Bingöl, E. (2018). Güneydoğu Anadolu Bölgesi Çanak Çömleksiz Neolitik Dönem Dikilitaş Geleneğinin Gelişimi ve Simgeciliği. (Yayımlanmamış Yüksek Lisans Tezi). Bilecik Şeyh Edebali Üniversitesi Sosyal Bilimler Enstitüsü, Bilecik.

Cauvin, J. (2000). The Symbolic Foundations of the Neolithic Revolution in the Near East. Ian Kuijt (Ed.), Life in Neolithic Farming Communities: Social Organization, Identity and Differentiation (pp.235-249). New York: Kluwer Academic/ Plenum Publishers.

Clark, J.G.D., (1980). Prehistoric Europe. London.

Çambel, H., Braidwood, R. J., Özdoğan, M. ve Schirmer, W. (1986). 1984 Yılı Çayönü Kazısı. VII. Kazı Sonuçları Toplantısı, Ankara, 37-52.

Çelik, B. (2003). Şanlıurfa Kent Merkezinde Çanak Çömleksiz Bir Neolitik Yerleşim: Yeni Mahalle. (Yayımlanmamış Yüksek Lisans Tezi). Hacettepe Üniversitesi Sosyal Bilimler Enstitüsü, Ankara. 
Çelik, B. (2005). Şanlıurfa-Yeni Mahalle, Karahan Tepe, Sefer Tepe ve Hamzan Tepe yerleşimlerinin Işı̆̆ Altında Güneydoğu Anadolu Bölgesinde Çanak Çömleksiz Neolitik Dönem. (Yayınlanmamış Doktora Tezi). Hacettepe Üniversitesi Sosyal Bilimler Enstitüsü, Ankara.

Çelik, B. (2006). Sefer Tepe: A New Pre-Pottery Neolithic Site in Southeastern Turkey. Neo-Lithics: The Newsletter of Southwest Asian Neolithic Research (1), Berlin, 23-25.

Çelik, B. (2015a). Şanlıurfa İli Merkez İlçesi Neolitik Çağ ve Öncesi Yüzey Araştırması, 2013. 32. Araştırma Sonuçları Toplantısı 2. Cilt, Kültür ve Turizm Bakanlığı Yayınları, Ankara, 311-328.

Çelik, B. (2015b). Differences and Similarities between the Settlements in Sanlıurfa Region where "T" Shaped Pillars are Discovered (Şanlıurfa Bölgesinde "T" Şeklinde Dikmetaş Bulunan Yerleşmelerin Farkl11ık ve Benzerlikleri). Türkiye Bilimler Akademisi Arkeoloji Dergisi (TÜBA-AR) sayı: 17/2014, Türkiye Bilimler Akademisi Yayınları, Ankara, 9-24.

Çelik, B. (2016). Şanlıurfa İli Merkez İlçesi Neolitik Çağ ve Öncesi Yüzey Araştırması.33. Araştırma Sonuçları Toplantısı 2. Cilt, T.C. Kültür ve Turizm Bakanlığı Yayınları, Ankara, 409-426.

Çelik, B. (2017). A New Pre-Pottery Neolithic site in Southeastern Turkey: Ayanlar Höyük (Gre Hut). Documenta Praehistorica XLIV, 360-367.

Çelik, B. (2018). Şanlıurfa İli Neolitik Dönem Yüzey Araştırması, 2018. Karadeniz, 40, 52-63.

Çelik, B. ve Tosyagülü Ç. H. (2020). Harbetsuvan Tepesi 2019 Yılı Kazı Çalışması. Karadeniz Uluslararası Bilimsel Dergi 48, 303-326.

Çelik, B. ve Uludağ, C. (2019). 2017 ve 2018 Yılı Harbetsuvan Tepesi Kazı ve Temizlik Çalışması. 41. Kazı Sonuçları Toplantısı 1. Cilt, Kültür ve Turizm Bakanlığı Yayınları, Ankara, 337-356.

Dietrich, O., Notroff, J. ve Schmidt, K. (2015). Göbeklitepe-Dünya Kültür Mirasına Girme Yolunda Olağandış1 Bir Erken Neolitik Buluntu Yeri. Kültürlerin Köprüsü Anadolu, Türk-Alman Eskiçă̆ Bilimlerinde Güncel Bilimsel Araştırmalar ve Yeni Bakış Açıları, (in) Bonn vom 7. bis 9. Juli 2014, Ed. Ünsal Yalçın \& HansDieter Bienert, Museum Bochum, Bonn, 91-109.

Dietrich, O., Köksal-Schmidt, Ç., Kürkçüoğlu, C., Notroff, J. ve Schmidt, K. (2012). Göbeklitepe. Aktüel Arkeoloji Dergisi, 26, 50-53.

Dietrich, O., Köksal-Schmidt, Ç. Notroff, J., ve Schmidt, K. (2013). Establishing a Radiocarbon Sequence for Göbeklitepe. State of Research and New Data. Neo-Lithics 1/13, 36-41.

Dietrich, O., Notroff, J. ve ark. (2016). Göbeklitepe, Anlage H. Ein Vorbericht beim Ausgrabungsstand von 2014. In Ü. Yalçın (Ed.), Anatolian Metal VII, Anatolien und seine Nachbarn vor 10.000 Jahren, (pp.5369). Bochum: Deutschen Bergbau-Museum.

Driesch, A. ve Peters, J. (1999). Vorläufiger Bericht über die archäozoologischen Untersuchungen am Göbeklitepe und am Gürcütepe bei Urfa, Türkei. Istanbuler Mitteilungen des Deutschen Archäologischen Instituts 49, 23-39.

Erim-Özdoğan, A. (2007). Çayönü. M. Özdoğan ve N. Başgelen (Ed.), Türkiye'de Neolitik Dönem içinde (s.67-97). İstanbul: Arkeoloji ve Sanat Yayınları.

Güler, M., Çelik, B. ve Güler, G. (2012). Viranşehir ilçesinden Yeni Çanak Çömleksiz Neolitik Dönem Yerleşimleri. Ankara Üniversitesi Dil ve Tarih Coğrafya Fakültesi, Anadolu / Anatolia 38, 157-180.

Güler, G., Çelik, B. ve Güler, M. (2013). New Pre-Pottery Neolithic sites and cult centres in the Urfa Region. Documenta Praehistorica XL, 291-303.

Hauptmann, H. (1993), Ein Kultgebäude in Nevali Çori. Frangipane, M. ve. ark. (Ed.), Between the Rivers and over the Mountains. Archaeologica Anatolica e Mesopotamica, Alba Palmieri Dedicata (pp.37-69). Rome. 
Hauptmann, H. (2007a). Nevali Çori. 12.000 Yll Önce Uygarlı̆̆ın Anadolu'dan Avrupa'ya Yolculuğunun Başlangıcı-Neolitik Dönem, Yapı Kredi Yayınları, İstanbul, 97-98.

Hauptmann, H. (2007b). Nevali Çori ve Urfa Bölgesinde Neolitik Dönem: Genel Bir Bakış. M. Özdoğan N. Başgelen (Ed.), Anadolu'da Uygarlı̆̆ın Doğuşu ve Avrupa'ya Yayllımı: Türkiye'de Neolitik Dönem; Yeni Kazılar- Yeni Bulgular (s.131-165). İstanbul: Arkeoloji ve Sanat Yayınları.

Hauptmann, H. (2011). The Urfa Region. M. Özdoğan. N. Başgelen-P. Kuniholm (Eds.), The Neolithic in Turkey Vol.2 (pp.85-138). İstanbul: Arkeoloji ve Sanat Yayınları.

Hauptmann, H. (2012a). Frühneolithische Kultbilder in der Kommagene. In J. Wagner (Ed.), Gottkönige am Euphrat. Neue Ausgrabungen und Forschungen in Kommagene (pp.12-22). Darmstadt/Mainz: Philipp von Zabern.

Hauptmann, H. (2012b). Nevali Çori. Aktüel Arkeoloji, İstanbul, 96-106.

Hayden, B. (2015). Uygarlığın Kökeni Şölenler. Aktüel Arkeoloji, İstanbul, 80-89.

İpek, B. ve Çiftçi, Y. (2020). Boncuklu Tarla Doğu Alanı Çanak Çömleksiz Neolitik Dönem Mimarisi ve Köy-Mekân Organizasyonu. Mukaddime, 11(1), 212-234.

Karul, N. (2011). Gusir Höyük. In. M. Özdogan, N. Başgelen ve P. Kuniholm (Ed.), The Neolithic in Turkey/ The Tigris Basin (pp.1-17). İstanbul: Arkeoloji ve Sanat Yayınları.

Karul, N. (2013a). Eski Dünyanın İlk Köyleri Yerleşik Avcılar. Atlas Dergisi, Mart 2013 sayı: 240, Doğan Burda Yayıncılık, İstanbul, 82-96.

Karul, N. (2013b). Gusir Höyük/ Siirt; Yerleşik Avcılar. Arkeo Atlas (8), 22-30.

Kodaş, E. (2018). Yukarı Dicle'de Yeni Bir Çanak Çömleksiz Neolitik Yerleşim Yeri: Boncuklu Tarla Kazıları ve İlk Gözlemler. Arkeoloji ve Sanat Dergisi 158, 7- 20.

Kodaş, E. (2020). Kuzey Mezopotamya da Çanak-Çömleksiz Neolitik A Dönemine Tarihlenen Yeni Bir Kamu Binası Stelli Bina. Aktüel Arkeoloji, 1(73), 22-27.

Maeda, O., Hongo, H. ve Tanno, K. (2016). Yerleşik Bir Köyde Avcı Toplayıcı Yaşam: Hasankeyf. Aktüel Arkeoloji Dergisi, İstanbul, 40-47.

Maher, L. A., Stock, J.T., Finney, S. ve ark. (2011). A Unique Human-Fox Burial from a Pre-Natufian Cemetery in the Levant (Jordan). PLoS ONE 6(1), 1-10.

Mitten, Steven (1998). Aklın Tarih Öncesi (İrem Kutluk, Çev). Ankara: Dost Kitapevi Yayınları.

Miyake, Y. (2016). Tarih Öncesi Dönemde Hasankeyf. Varlık Yokluk Savaşında Hasankeyf, Aktüel Arkeoloji Dergisi, İstanbul, 28-39.

Notroff, J., Dietrich, O., Peters, J. ve ark. (2015). Uygarlığın Doğuşunda Göbeklitepe. Aktüel Arkeoloji Dergisi, İstanbul, 52-69.

Notroff, J., Dietrich, O., Dietrich, L., Lelek, C. T., Kinzel, M., Schlindwein, J.,...Clare, L. (2017). More than a vulture: A response to Sweatman and Tsikritsis. Mediterranean Archaeology and Archaeometry, vol. $17(2), 57-74$

Özdoğan, A. (1994). Çayönü Yerleşmesinin Çanak Çömleksiz Neolitikteki Yeri (Kü̧̧ük Buluntuların Yardımıyla) Metin ve katalog (2. cilt). (Doktora Tezi). İstanbul Üniversitesi Sosyal Bilimler Enstitüsü, İstanbul.

Özdoğan, A. (1995). Life at Çayönü During the Pre-Pottery Neolithic Period (according to the artifactual assemblage). Halet Çambel için Prehistorya Yazıları (Readings in Prehistory Studies Presented to Halet Çambel), Graphis Yayınları, İstanbul, 79-100. 
Özdoğan, M. ve Özdoğan, A. (1998). Buildings of Cult and the Cult of Buildings. G. Arsebük, M. Mellink ve W. Schirmer (Ed.), Light on Top of the Black Hill Studies Presented to Halet Çembel (pp.581-601). İstanbul: Ege Yayınları.

Özdoğan, M. (2007). Bazı Genellemeler Öngörüler. M. Özdoğan ve N. Başgelen (Ed.), Anadolu'da Uygarlığın Doğuşu ve Avrupa'ya Yayılımı, Türkiye'de Neolitik Dönem, Yeni Kazılar, Yeni Bulgular içinde (s.441-458). İstanbul: Arkeoloji ve Sanat Yayınlar1.

Peters, J. ve Schmidt, K. (2004). Animals in the symbolic world of Pre-Pottery Neolithic Göbeklitepe, southeastern Turkey: a preliminary assessment. Anthropozoologica 39 (1), 179-218.

Piesker, K. (2014). Göbeklitepe-Bauforschung in den Anlagen C und E in den Jahren 2010 und 2012. Zeitschrift für Orient-Archäologie 7, Berlin, 14-54.

Renfrew, C. ve Bahn, P. (2017). Arkeoloji: Kuramlar, Yöntemler ve Uygulama (Gürkan Ergin, Çev.). İstanbul: Homer Kitabevi.

Schirmer, W. (1990). Some Aspects of Building at the Aceramic-Neolithic Settlement of Çayönü Tepesi. World Archaeology. 21/3, 363-387.

Schmidt, K. (1998). Beyond Daily Bread: Evidence of Early Neolithic Ritual from Göbeklitepe. Neo-lithics 2/98, 1-5.

Schmidt, K. (2000). Zuerst kam der Tempel, dann die Stadt. Vorläufiger Bericht zu den Grabungen am Göbeklitepe und am Gürcütepe 1995-1999. Istanbuler Mitteilungen 50, 7-41.

Schmidt, K. (2005). 'Ritual Centers' and the Neolithisation of Upper Mesopotamia. Neo-Lithics, Dialogue on the Early Neolithic Origin of Ritual Centers, 2/05, 13-21.

Schmidt, K. (2007a). Göbeklitepe. M. Özdoğan ve N. Başgelen (Ed.), Anadolu'da Uygarlı̆ğn Doğuşu Ve Avrupa'ya Yayılımı; Türkiye'de Neolitik Dönem/Yeni Kazılar-Yeni Bulgular içinde (s.115-141). İstanbul: Arkeoloji ve Sanat Yayınları.

Schmidt, K. (2007b). Taş Çă̆ı Avcılarının Gizemli Kutsal Alanı Göbeklitepe-En Eski Tapınağı Yapanlar (R. Aslan, Çev.). İstanbul: Arkeoloji ve Sanat Yayınları.

Schmidt, K. (2007c). Göbeklitepe Yuvarlak Yapılar ve Kabartmalar. 12.000 Yll Önce Uygarliğın Anadolu'dan Avrupa'ya Yolculuğunun Başlangıcı Neolitik Dönem, Yapı Kredi Yayınları, İstanbul, 33-44.

Schmidt, K. (2008a). Göbeklitepe - Enclosure C. Neo-Lithics 2/08, 27-32.

Schmidt, K. (2008b). Göbeklitepe Kazısı 2006 Yılı Raporu. 29. Kazı Sonuçları Toplantısı 2. cilt, Kocaeli 2007, Kültür ve Turizm Bakanlığı yayınları, Ankara, 417-428.

Schmidt, K. (2009). Göbeklitepe Kazısı 2007 Yılı Raporu. 30. Kazı Sonuçlarl Toplantısı 3. cilt, Ankara 2008, Kültür ve Turizm Bakanlığı Yayınları, Ankara, 163-182.

Schmidt, K. (2010a). Göbeklitepe Kazısı 2008 Yılı Raporu. 31.Kazı Sonuçları Toplantısı 1. cilt, Denizli 2009, Kültür ve Turizm Bakanlığı Yayınları, Ankara, 241-264.

Schmidt, K. (2010b). Göbeklitepe-the Stone Age Sanctuaries. New results of ongoing excavations with a special focus on sculptures and high reliefs. Documenta Praehistorica 37, 239-256.

Schmidt, K. (2011). Göbeklitepe Kazısı 2009 Y1lı Raporu. 32. Kazı Sonuçları Toplantıs1 2. cilt, İstanbul 2010 , Kültür ve Turizm Bakanlığı Yayınları, Ankara, 209-224.

Schmidt, K. (2012). Göbeklitepe Kazısı 2010 Y1lı Raporu. 33. Kazı Sonuçları Toplantısı 3. cilt, Malatya 2011, Kültür ve Turizm Bakanlığı Yayınları, Ankara, 319-340. 
Tunçdilek, N. (1971). Güneybatı Asya Fiziki Ortam. İstanbul: İstanbul Üniversitesi Coğrafya Enstitüsü Yayınları.

Türkcan, U.A. (2006). Çanak Çömleksiz Neolitik Dönem Yukarı Mezopotamya Anıtsal Kült Binaları ve Gelişimi (Doktora Tezi). Hacettepe Üniversitesi Sosyal Bilimler Entitüsü, Ankara.

Watkins, T. (2014). İnanca Yolculuk: Göbekli Tepe. Aktüel Arkeoloji Dergisi 41, 34-49.

Willcox, G. ve Savard, M. (2007). Güneydoğu Anadolu'da Tarımın Benimsenmesine İlişkin Botanik Veriler. M. Özdoğan ve N. Başgelen (Ed.) Anadolu'da Uygarlığın Doğuşu ve Avrupa'ya Yayılımı-Türkiye'de Neolitik Dönem-Yeni Kazılar, Yeni Bulgular (s.427-440). İstanbul: Arkeoloji ve Sanat Yayınları. 


\section{Harita, Resim, Tablo ve Grafikler}

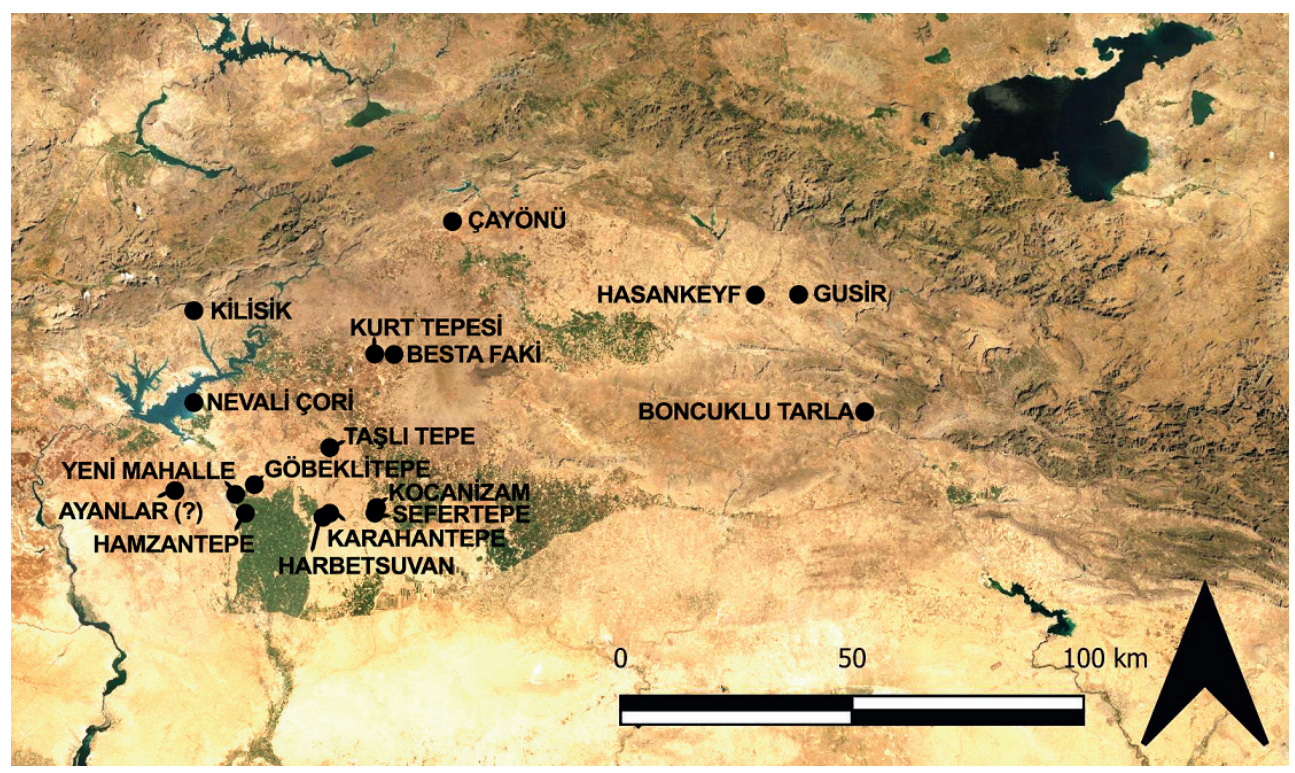

Harita 1. Güneydoğu Anadolu'da Dikilitaşlı Yapılar İçeren Neolitik Alanlar

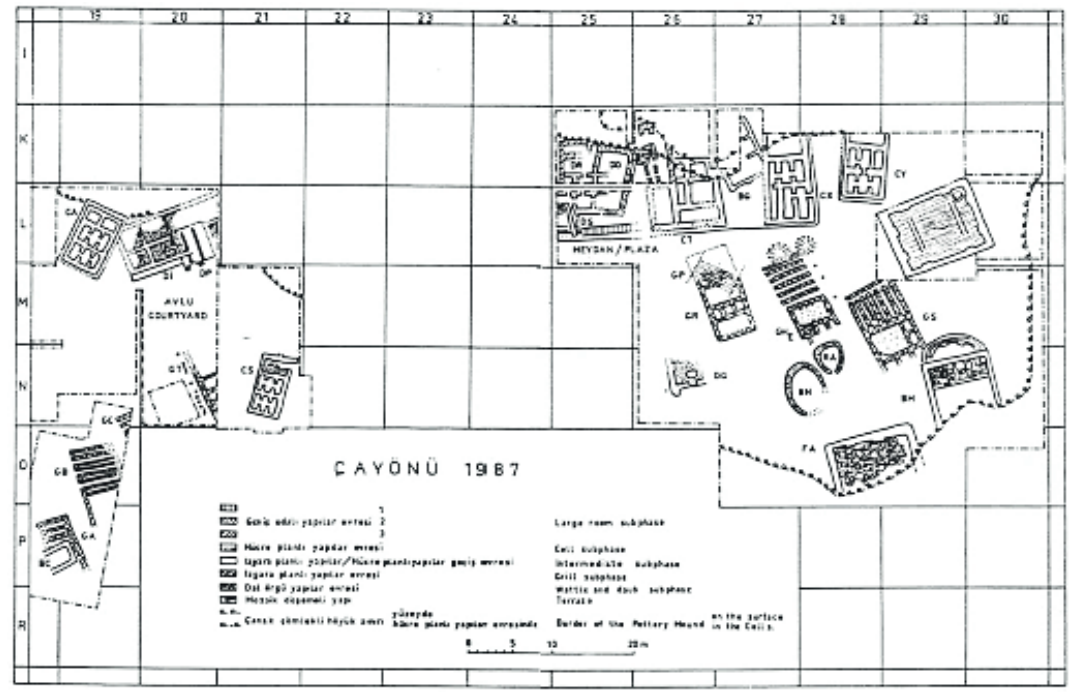

Resim 1. Çayönü Yerleşim Planı ve Doğuda Yer Alan Meydan (Plaza) ve Kült Yapıları (Özdoğan ve Özdoğan 1989, Fig. 1) 


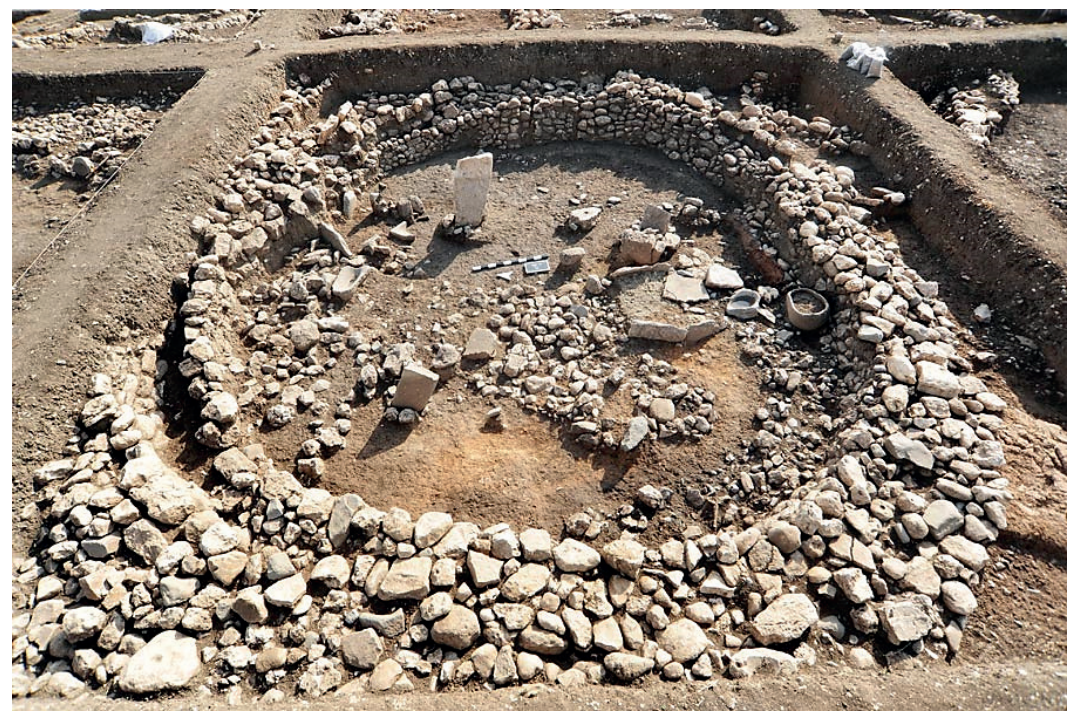

Resim 2. Gusir Höyük Üst Tabakadaki Dikilitaşlı Büyük Yapı (Karul, 2013a, s. 90)

12

13

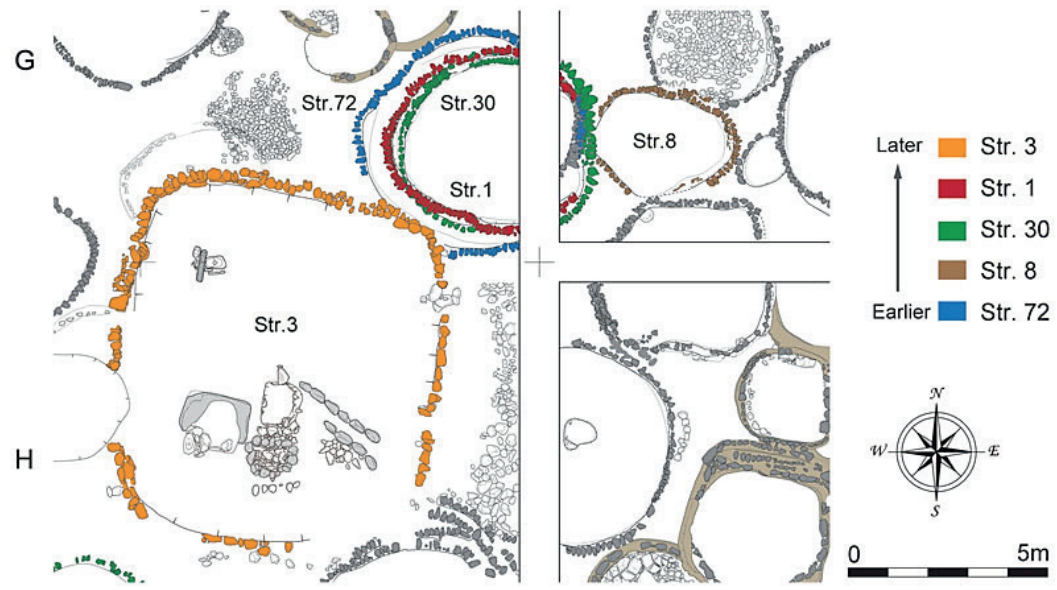

Resim 3. Hasankeyf Höyük G12 ve H12 Açmalarındaki Yapıların Planı (Maeda, 2018, Fig. 2) 


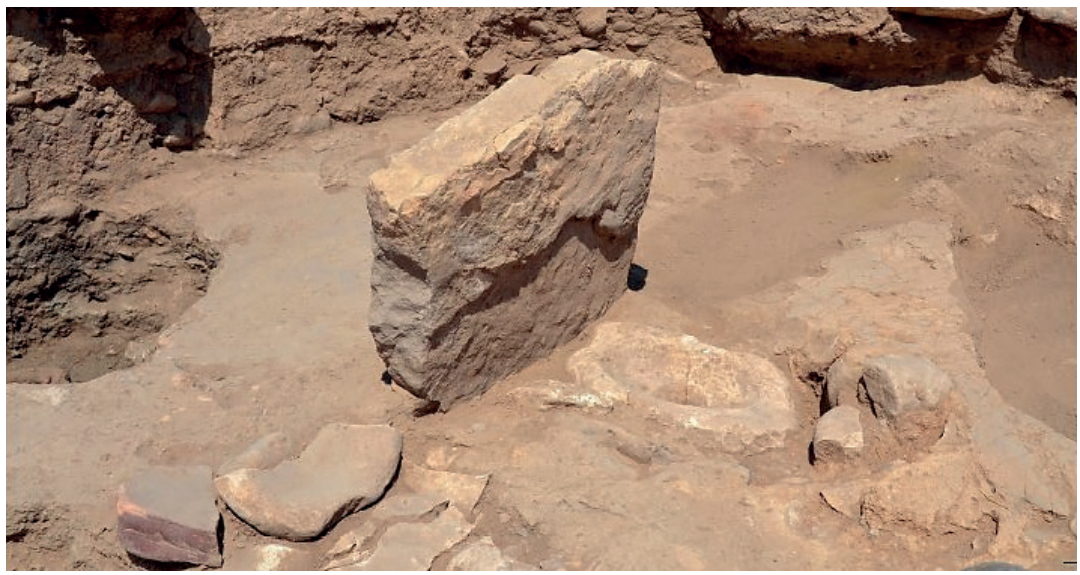

Resim 4. Hasankeyf Höyük 3 no'lu Yapıda Bulunan Kırık İn Situ Dikilitaş (Miyake, 2016, s. 29)

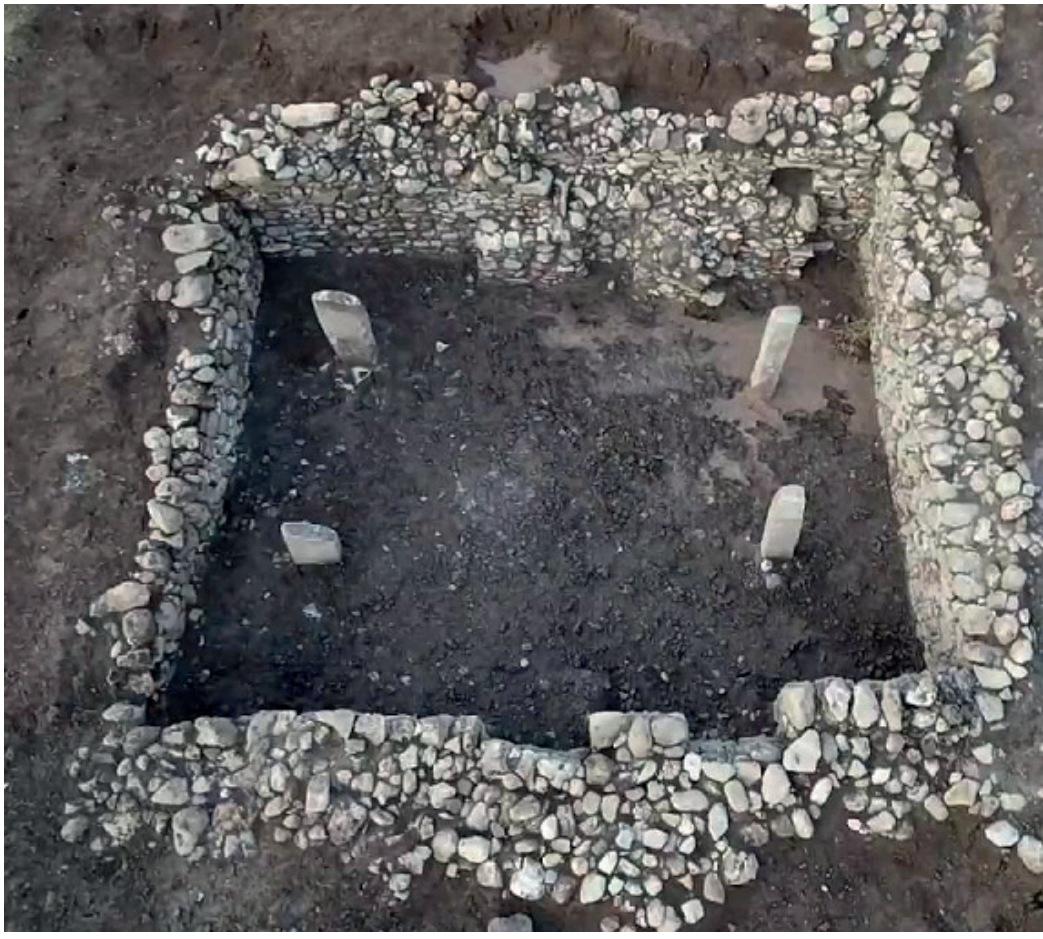

Resim 5. Boncuklu Tarla Kamu Binası (Stelli Bina) (Kodaş, 2020, s. 24) 


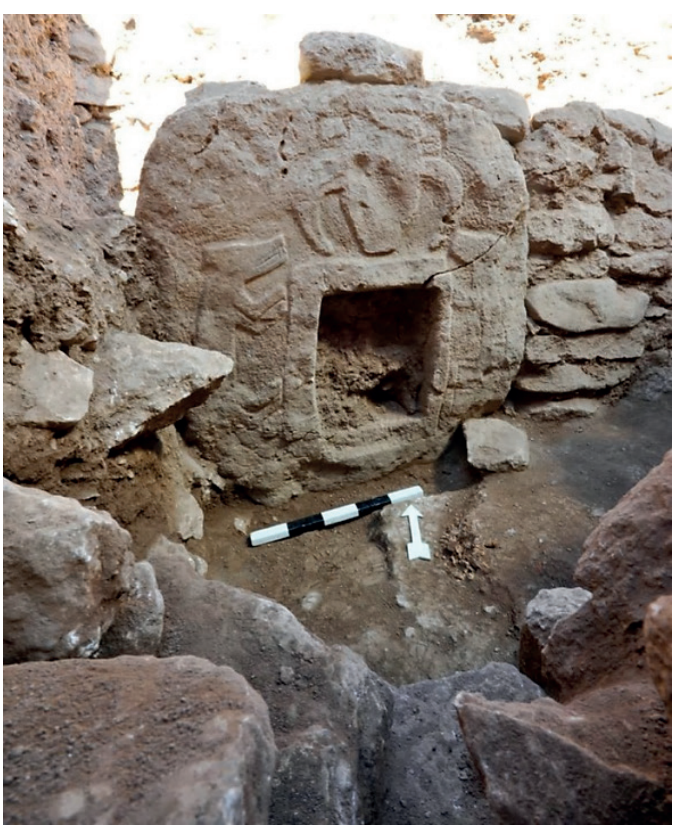

Resim 6. Göbeklitepe B Yapısı'nın Kabartmalı İn Situ Kapı Giriş Taşı (Dietrich ve ark., 2012, s. 52)

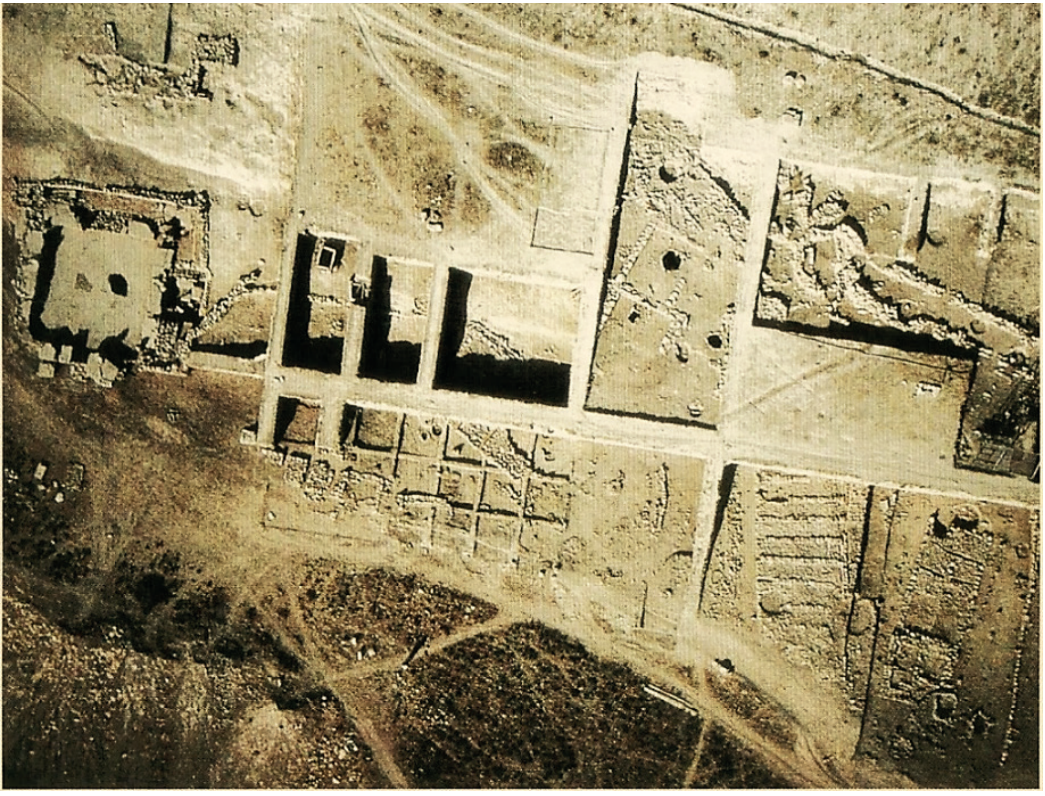

Resim 7. Nevali Çori Kazı Alanları ve Kare Planlı Kült Yapısı (Hauptmann, 2007c, 98) 


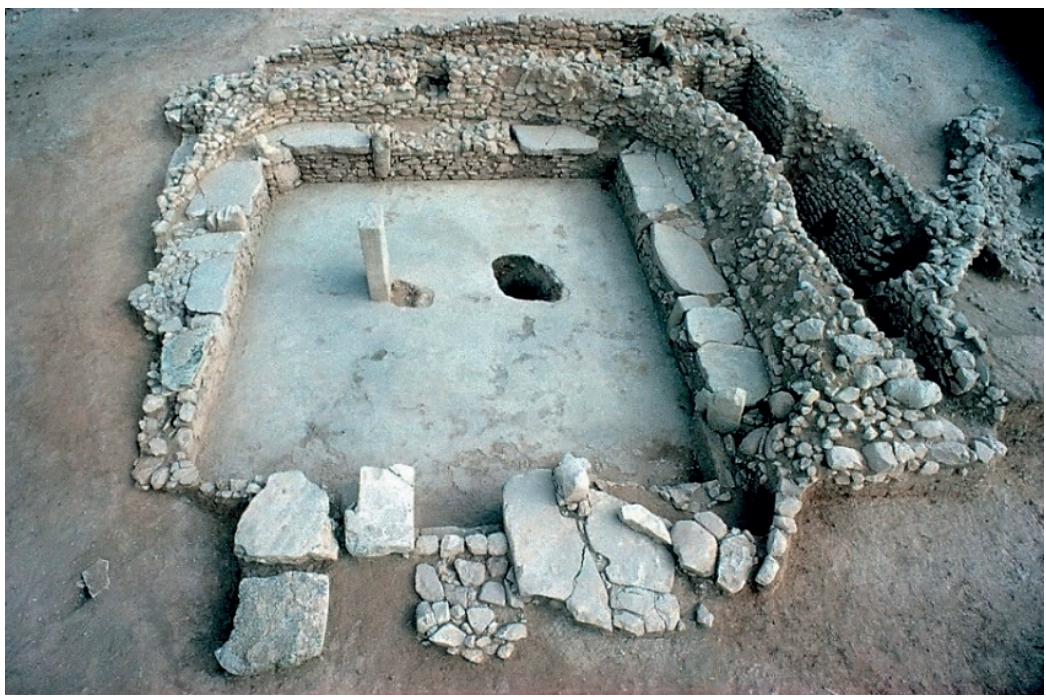

Resim 8. Nevali Çori Kült Yapı III'ün Giriş Tarafından Görünümü (Hauptmann, 2012b, Res. 6)

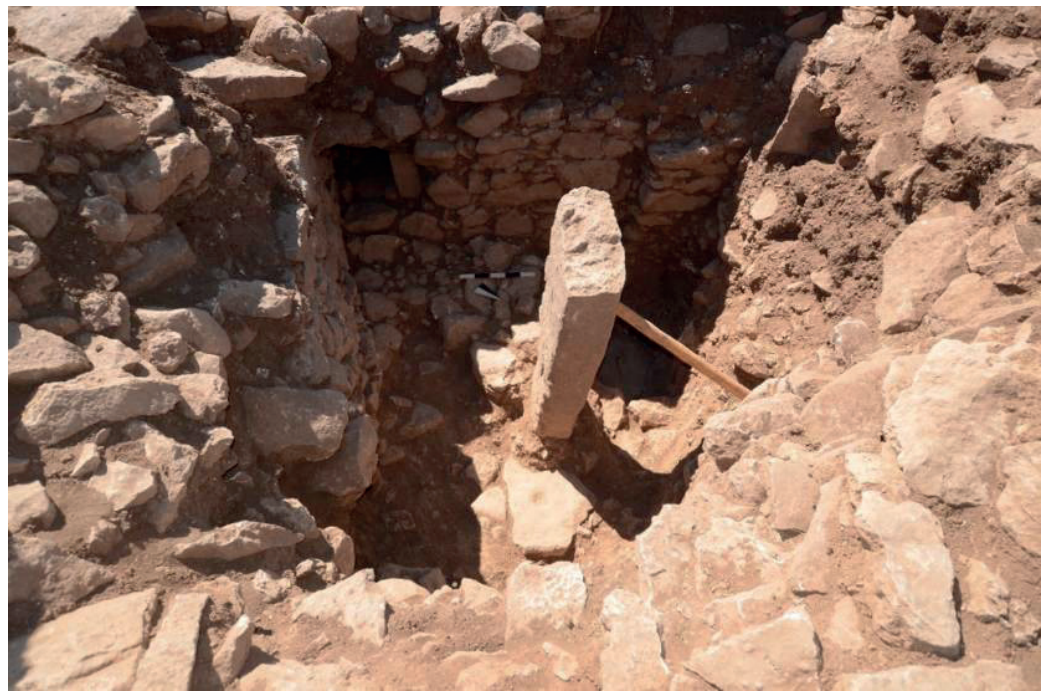

Resim 9. Harbetsuvan Tepesi K11 Açmasında Bulunan Mekânın Duvarları ve Giriş Bölümü (Çelik ve Uludağ 2019, Res. 3) 


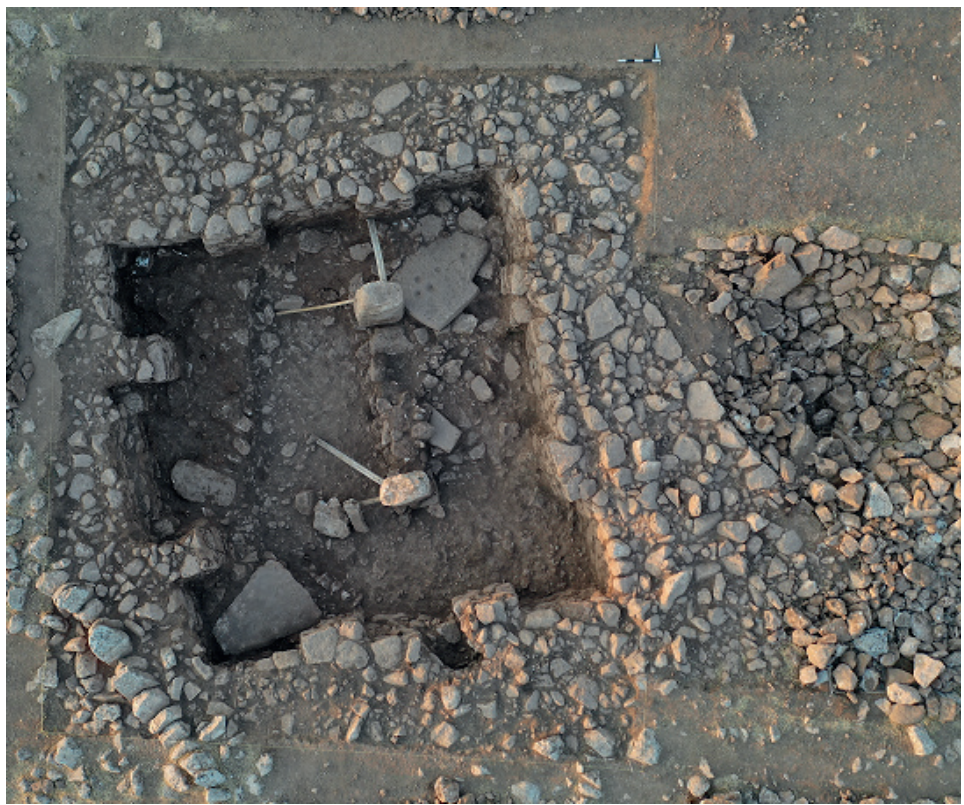

Resim 10. Harbetsuvan Tepesi Karşılıklı İki Dikilitaşın, Niş ve Yapı Girişinin Birlikte Bulunduğu K-5 Açmasının Üstten Görünümü (Çelik ve Tosyagülü 2020, Res. 6)

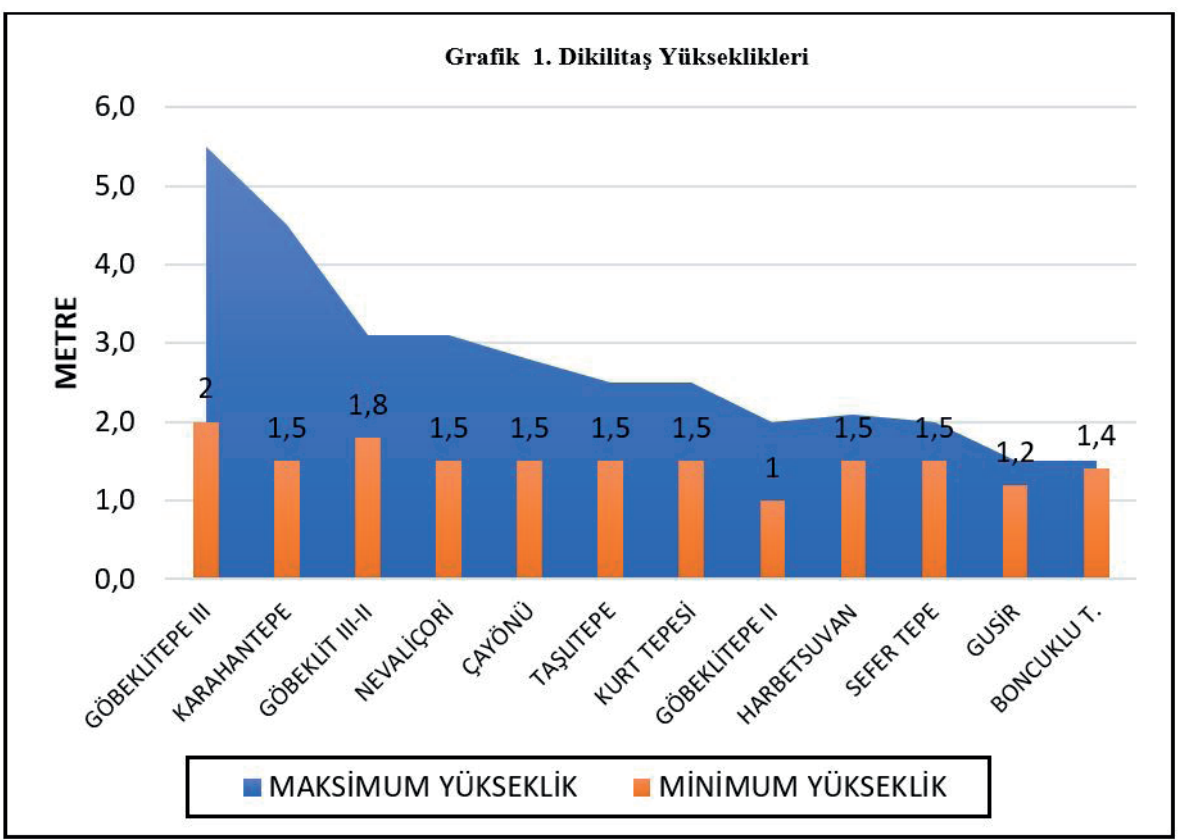




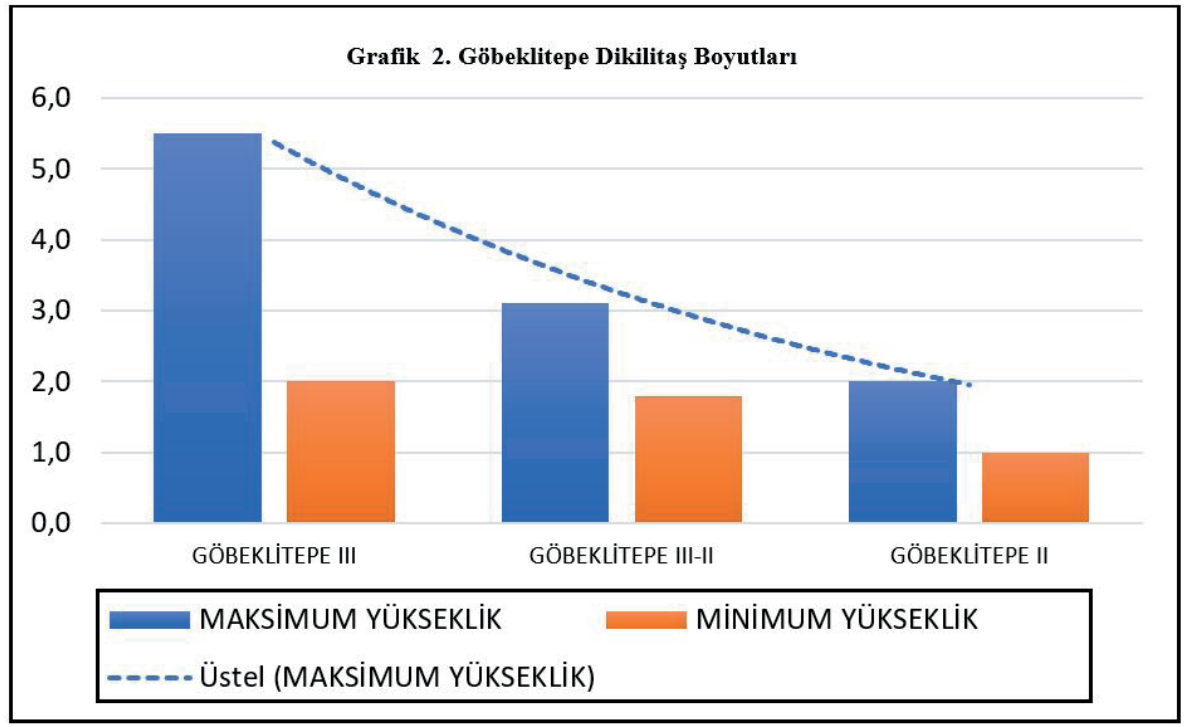

Grafik 3. Göbeklitepe Yuvarlak Planlı Yapıların Hayvan Tasvirlerinin Yapılara Göre Dağılımı

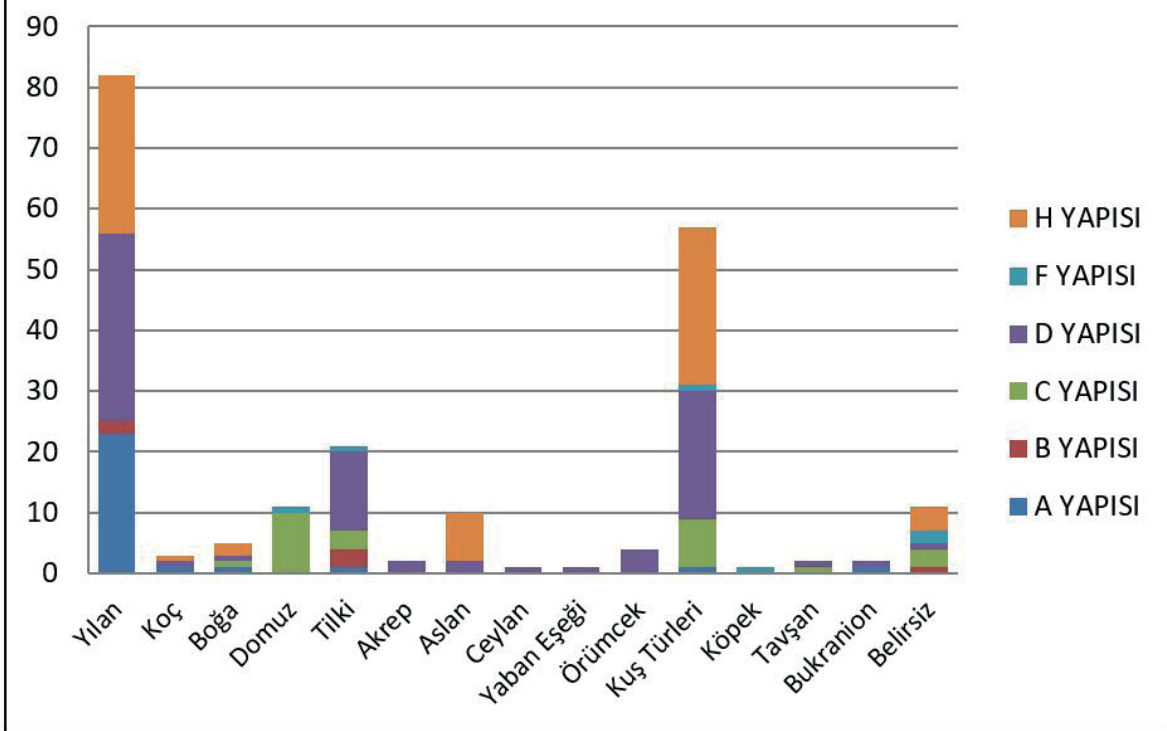




\begin{tabular}{|c|c|c|c|c|c|c|c|}
\hline & 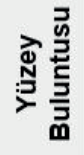 & $\begin{array}{l}\overline{\mathbb{N}} \\
\text { צn}\end{array}$ & 톤 & 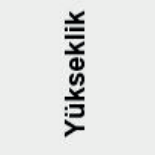 & $\begin{array}{l}\frac{\underline{\underline{\underline{E}}}}{\underline{\underline{E}}} \\
\underline{\underline{\underline{J}}}\end{array}$ & 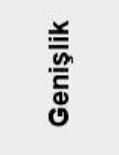 & 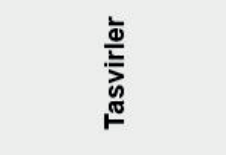 \\
\hline \multicolumn{8}{|c|}{ Şanlıurfa Bölgesi'nde Ele Geçen Dikilitaşlar } \\
\hline $\begin{array}{l}\text { Göbeklitepe } \\
\text { (Yuvarlak } \\
\text { Yapılar) }\end{array}$ & $?$ & 71 & $T$ ve ters $L$ & $1.90-5.5 \mathrm{~m}$ & $30-50 \mathrm{~cm}$ & $\begin{array}{l}70-125 \\
\mathrm{~cm}\end{array}$ & $\begin{array}{l}\text { Grafik 3'te yer } \\
\text { almaktadır }\end{array}$ \\
\hline $\begin{array}{l}\text { Göbeklitepe } \\
\text { (Dikdörtgen } \\
\text { Yapılar) }\end{array}$ & $?$ & 43 & $T$ ve ters $L$ & $1-2 \mathrm{~m}$ & $25 \mathrm{~cm}$ & $50 \mathrm{~cm}$ & $\begin{array}{c}\text { El, Kol, Akbaba ve } \\
\text { Aslan }\end{array}$ \\
\hline Nevali Çori & $?$ & 29 & $T$ ve ters $L$ & $1.5-3.15 \mathrm{~m}$ & $30-45 \mathrm{~cm}$ & $80 \mathrm{~cm}$ & El ve Kol \\
\hline Harbetsuvan & 14 & 16 & $\mathrm{~T}$ ve ters $\mathrm{L}$ & $1.5-2.05 \mathrm{~m}$ & $20-35 \mathrm{~cm}$ & $40-75 \mathrm{~cm}$ & El ve Kol \\
\hline Karahan Tepe & 266 & & T-biçimli & & $20-25 \mathrm{~cm}$ & $40-70 \mathrm{~cm}$ & $\begin{array}{c}\text { Yilan, Tavşan, } \\
\text { Ceylan }\end{array}$ \\
\hline Sefer Tepe & 16 & & T-biçimli & $1.5-2.0 \mathrm{~m}$ & $20-30 \mathrm{~cm}$ & $50-70 \mathrm{~cm}$ & Boğa Başı Taslağı \\
\hline Hamzan Tepe & 1 & & T-biçimli & & $22 \mathrm{~cm}$ & $50-70 \mathrm{~cm}$ & $?$ \\
\hline Taşlı Tepe & 4 & & T-biçimli & $1.5-2.0 \mathrm{~m}$ & $20-25 \mathrm{~cm}$ & $50 \mathrm{~cm}$ & $?$ \\
\hline Kurt Tepesi & 2 & & T-biçimli & $2.5 \mathrm{~m}$ & $25 \mathrm{~cm}$ & $50-70 \mathrm{~cm}$ & Kravat, Șevron \\
\hline Kocanizam & 1 & & $\begin{array}{l}\text { T-biçimli } \\
(?)\end{array}$ & & & & $?$ \\
\hline Besta Faki & 1 & & $\begin{array}{l}\text { T-biçimli } \\
\text { (?) }\end{array}$ & & & $70 \mathrm{~cm}$ & ? \\
\hline \multicolumn{8}{|c|}{ Yukarı Dicle Bölgesi'nde Ele Geçen Dikilitaşlar } \\
\hline Gusir Höyük & & $?$ & "I" biçimli & $1.2-1.5 \mathrm{~m}$ & & & Daire (kazıma) \\
\hline $\begin{array}{l}\text { Hasankeyf } \\
\text { Höyük }\end{array}$ & & 1 & "I" biçimli & $?$ & & $85 \mathrm{~cm}$ & \\
\hline Çayönü & & $?$ & "I" biçimli & $1.5-2.80 \mathrm{~m}$ & & & \\
\hline $\begin{array}{l}\text { Boncuklu } \\
\text { Tarla }\end{array}$ & & 4 & "I" biçimli & $1.4-1.5 \mathrm{~m}$ & $25-30 \mathrm{~cm}$ & & \\
\hline
\end{tabular}

Tablo 1. Güneydoğu Anadolu Bölgesi Dikilitaşlarının Boyutları, Form ve Betimlemeleri 
